\title{
Uranium occurrences in the Horton Group of the Windsor area, Nova Scotia and the environmental implications for the Maritimes Basin
}

\author{
Robert J. Ryan ${ }^{*}$ and Anne Marie O’Beirne-Ryan ${ }^{2}$ \\ 1. Nova Scotia Department of Natural Resources, Box 698, Halifax, Nova Scotia B3J 2T4, Canada \\ 2. Department of Earth Sciences, Dalhousie University, Halifax, Nova Scotia B3H 3J5, Canada \\ *Corresponding author: < rjryan@gov.ns.ca>
}

Date received: 23 June 2009 Date accepted: 12 November 2009

\begin{abstract}
Uranium enrichment occurs at numerous localities in the basin-fill units of the Maritimes Basin, and in the adjacent basement rocks in Atlantic Canada. The exploration model applied to the sandstone-hosted occurrences is that of a uranium roll-front, similar to the deposits of Texas and the western United States. The recognition of deeply weathered granitoid rocks below the unconformity of the Horton Group on the South Mountain Batholith, however, suggests an additional genetic link to regolith-related unconformity deposits, such as the Athabasca Basin of Saskatchewan. There is no doubt that roll-front type uranium mineralization occurs in Horton Group sandstone; however, the source of the uranium within the system may be related to weathered horizons in the basement rocks beneath the Horton Group and not exclusively the result of diagenetic change in the sandstone. Uranium occurrences are numerous in the type area of the Horton Group near Windsor, Nova Scotia. The most notable occurrence is at Three Mile Plains where Saarberg Interplan Canada Ltd. drilled over 40 diamond-drill holes from 1978 to 1981. Significant uranium mineralization is stratigraphically restricted to the top of the Horton Bluff Formation and base of the Cheverie Formation near the Horton Bluff-Cheverie unconformity. The uranium mineralization can be divided into two types: (1) carbon and pyrite-related quartz sandstone type and (2) hematite arkosic sandstone type. Although this paper deals primarily with uranium and associated elements from occurrences in the Windsor area, the regional nature of the pre-Carboniferous weathering episode and the areal extent of Horton Group strata throughout eastern Canada suggests that uranium enrichment is likely more widespread than has been documented currently in the Maritimes Basin. Particular note should be taken in areas that have uranium occurrences within granitoid basement rocks adjacent to Carboniferous basin-fill. Preliminary leaching experiments of the mineralized rocks indicate that uranium and radon are easily leached from the samples and entering into the present-day environment.
\end{abstract}

\section{RÉSUMÉ}

L'enrichissement d'uranium survient en de nombreux endroits des unités sédimentaires du bassin des Maritimes, ainsi que dans les roches du socle adjacent au Canada atlantique. Le modèle d'exploration utilisé dans les minéralisations des grès est celui du front de minéralisation d'uranium, semblable à celui des gisements du Texas et dans l'Ouest des États-Unis. L'identification de roches granitoïdes fortement altérées sous la discordance du groupe Horton, dans la formation de batholithe South Mountain, semble toutefois suggérer la présence d'un autre lien génétique avec des gisements discordants associés au régolite, comme ce que l'on peut observer dans le bassin Athabasca, en Saskatchewan. Nul doute que la minéralisation de front d'uranium est présente dans les grès du groupe Horton. Toutefois, la provenance de l'uranium dans le système pourrait s'expliquer par des horizons météorisés dans les roches du socle sous-jacent du groupe Horton et non pas uniquement par un changement diagénétique survenu dans les grès. Les minéralisations d'uranium sont nombreuses dans la région type du groupe Horton, près de Windsor, en Nouvelle-Écosse. La minéralisation la plus notable se trouve à Three Mile Plains, où l'entreprise Saarberg Interplan Canada Ltd. a réalisé 40 trous de forage au diamant entre 1978 et 1981. La minéralisation d'uranium d'importance est délimitée au plan lithologique à la strate supérieure de la Formation de Horton Bluff et à la base de la Formation de Cheverie, à proximité de la discordance Horton Bluff-Cheverie. La minéralisation d'uranium peut se répartir en deux catégories : (1) des grès quartzeux associés au carbone et à la pyrite; et (2), des grès arkosiques ayant subi une hématisation. Bien que ce document traite pour l'essentiel de l'uranium et des éléments connexes minéralisés dans la région de Windsor, la nature régionale de la météorisation survenue avant le Carbonifère et la superficie de la lithologie du groupe Horton 
dans tout l'est du Canada, portent à croire que l'enrichissement d'uranium est vraisemblablement plus répandu que ce qui a été établi jusqu'ici dans le bassin des Maritimes. Il conviendrait de porter une attention particulière aux secteurs où une minéralisation d'uranium est observée dans les roches granitoïdes du socle qui jouxtent les unités sédimentaires du bassin du Carbonifère. Des essais préliminaires de lixiviation des roches minéralisées indiquent que les échantillons d'uranium et de radon sont facilement lessivés dans l'environnement actuel.

\section{[Traduit par la redaction]}

\section{INTRODUCTION}

The presence of anomalous levels of uranium, radium and radon in the Carboniferous Horton Group and underlying basement rocks of Atlantic Canada has been known for many years (Gross 1957; Brummer 1958) (Fig. 1). In the late 1970 s and early 1980s numerous companies conducted extensive uranium exploration programs in eastern Canada. Although exploration results were encouraging, public pressure in 1982 forced a moratorium in Nova Scotia on all exploration and prospecting for the commodity. The exploration model applied to the sandstone-hosted occurrences was that of a uranium roll-front, similar to the deposits of Texas and the western United States (Dunsmore 1977; Maynard 1983). The more recent recognition of deeply weathered granitoid rocks below the unconformity of the Horton Group on the South Mountain Batholith (O'Beirne-Ryan and Zentilli 2003) suggests an additional genetic link to regolith-related unconformity deposits such as the Athabasca Basin of Saskatchewan. There is no doubt of the presence of roll-fronts in the Horton Group sandstone, but the source of the uranium in the system may be related to the weathered horizons beneath the Horton Group and not exclusively the result of diagenetic change in the sandstone.

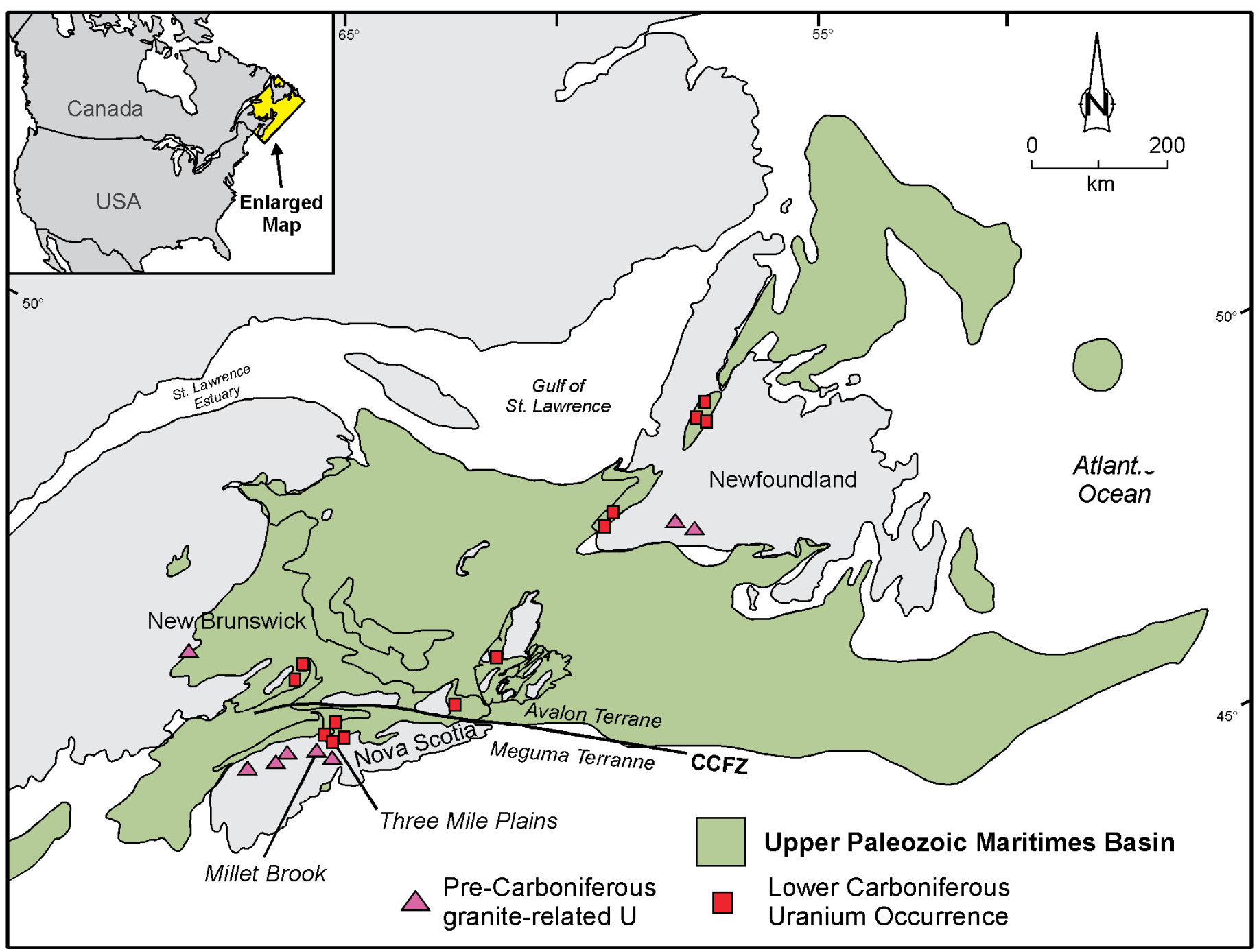

Fig. 1. Location of uranium occurrences in the Mississippian strata of the Maritimes Basin and in the adjacent basement rocks. CCFZ -Cobequid-Chedabucto Fault Zone. 
The granitoid rocks of the South Mountain Batholith in Nova Scotia contain numerous uranium deposits and occurrences (Fig. 1). These deposits are interpreted to have formed by fluid migration in the late stages of granitoid emplacement and occur within shear and fracture zones either within granitoid rocks or as peribatholithic occurrences in altered country rocks of the Meguma Group (Chatterjee et al. 1982; MacDonald 2001). The Millet Brook Deposit in the South Mountain Batholith is the largest $\left(450,000 \mathrm{~kg}\right.$ of $\left.\mathrm{U}_{3} \mathrm{O}_{8}\right)$ and best documented uranium deposit in the Maritime Provinces. The deposit also contains copper and silver. The dominant uranium-bearing mineral in the granitoid-hosted ore zones (veins) below $50 \mathrm{~m}$ is pitchblende (Chatterjee et al. 1982). In the uppermost $50 \mathrm{~m}$ of the deposit (Fig. 2) uranium occurs as the U-phosphate minerals torbenite, autunite, and $\mathrm{Pb}$-metaautunite (MacDonald 2001). It can be implied from the work of Chatterjee et al. (1982) and was suggested by MacDonald (2001) that this upper mineral assemblage is the result of surface weathering processes. Other minerals present in the upper zone include bornite, covellite, chalcocite, prousite, hematite, kaolin, and illite-smectite. All of these associated minerals are consistent with low temperature surface weathering processes. Similar occurrences of uranium are found in Devonian-Carboniferous granitic plutons elsewhere in the Maritime Provinces and in Newfoundland (Fig. 1).

The overall average background uranium content in the South Mountain Batholith is approximately $6 \mathrm{ppm}$ (MacDonald 2001). Weathering of the batholith and its contained uranium deposits to a depth of $10 \mathrm{~m}$, prior (and subsequent) to the deposition of the Horton Group sedimentary rocks would liberate approximately $190000000 \mathrm{~kg}$ of uranium with an average of 1 ppm depletion (Ryan and O'Beirne-Ryan 2007). The subsidence required during initial formation of the Maritimes Basin left much of the South Mountain Batholith exposed at surface in the upland region adjacent to the southern part of the Maritimes Basin. The uranium liberated from weathered

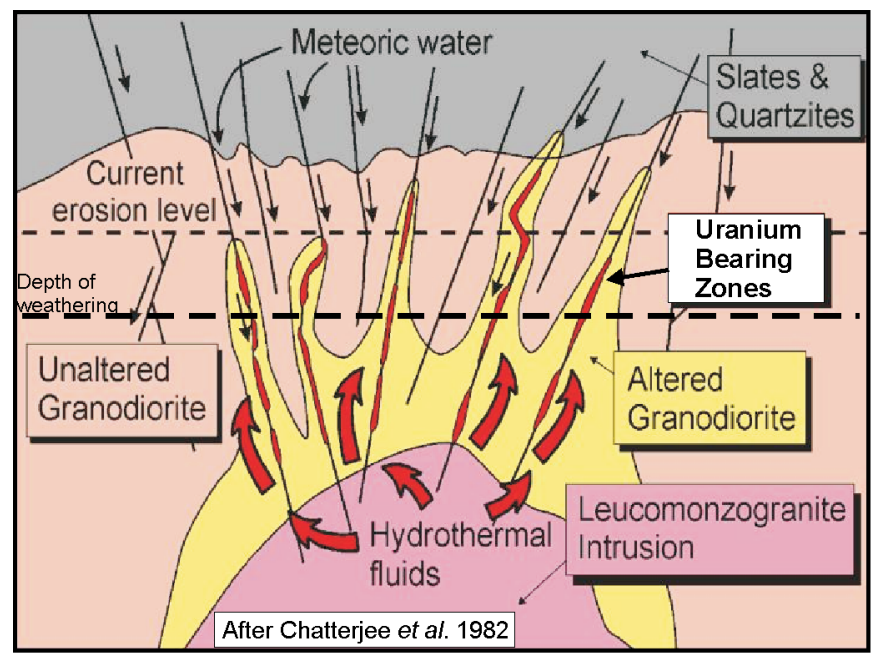

Fig. 2. Model for the uranium mineralization at Millet Brook, South Mountain Batholith, Nova Scotia. horizons in the granitoid rocks was incorporated into the surface water and subsequently introduced as uranium-enriched groundwater into the permeable sandstone and conglomerate aquifers of the Horton Group and/or younger permeable Carboniferous strata.

Most unconformity-type deposits are associated with Precambrian rocks in the McArthur Basin of Australia and the Athabasca Basin of Saskatchewan (Cameron 1983). These deposits are located at or near the base of sedimentary basins overlying the Precambrian unconformities. Sandstones dominate the basin-fill strata and the deposits are associated with graphite-rich faulted basement rocks (shear zones). Maynard (1983) suggested that almost all uranium concentrated in sedimentary rocks is derived from rocks with granitic composition. The role of regoliths in relation to the mineralization in the Athabasca Basin has been debated over the years by numerous authors (e.g., Dahlkamp 1984); however, the close spatial relationship of weathered mantles below these giant unconformity-uranium deposits strongly suggests some genetic connection.

Maynard et al.(1995) have suggested a genetic relationship of weathered hydrothermally altered granites (regolith) and the gold and uranium deposits of the Witwatersrand Basin. As in the case of the Athabasca deposits, much controversy exists about the nature of the Witwatersrand deposits. Most of the debate centres around whether the South African deposits are paleoplacers or related to metamorphic fluids (Phillips and Myers 1989). Sutton et al. (1990) argued that source area weathering was the main contributing factor to the Witwatersrand deposits rather than metamorphism. Maynard et al. (1995) cited the mineralogically supermature nature of the sandstone and conglomerate and the stratigraphic continuity of the units as evidence for a placer origin for the gold and uranium.

O'Beirne-Ryan and Zentilli (2003) and Ryan et al. (2005) suggested that some of the mineralogically mature sandstone of the Cretaceous and Carboniferous basins in Nova Scotia is probably related to the erosion of weathered profiles developed on the granitoid and metamorphic basement rocks or on similar rocks farther afield in the northern Appalachians. O'BeirneRyan and Zentilli (2003) provided evidence for three distinct episodes of weathering during which saprolite development occurred in southern Nova Scotia (Fig. 3). The present paper examines the significance of pre-Carboniferous saprolites as they relate to uranium enrichment in the Horton Group in Nova Scotia and in equivalent strata in the Maritimes Basin as a whole, and the related environmental implications.

\section{GENERAL GEOLOGY}

The rocks and saprolites referred to in this paper are located primarily in southern Nova Scotia that forms part of the Meguma terrane of the northern portion of the Appalachian orogen. The Appalachian orogen stretches from Newfoundland to southern United States. The Meguma terrane is thought to be an allochthonous fragment accreted onto the eastern mar- 


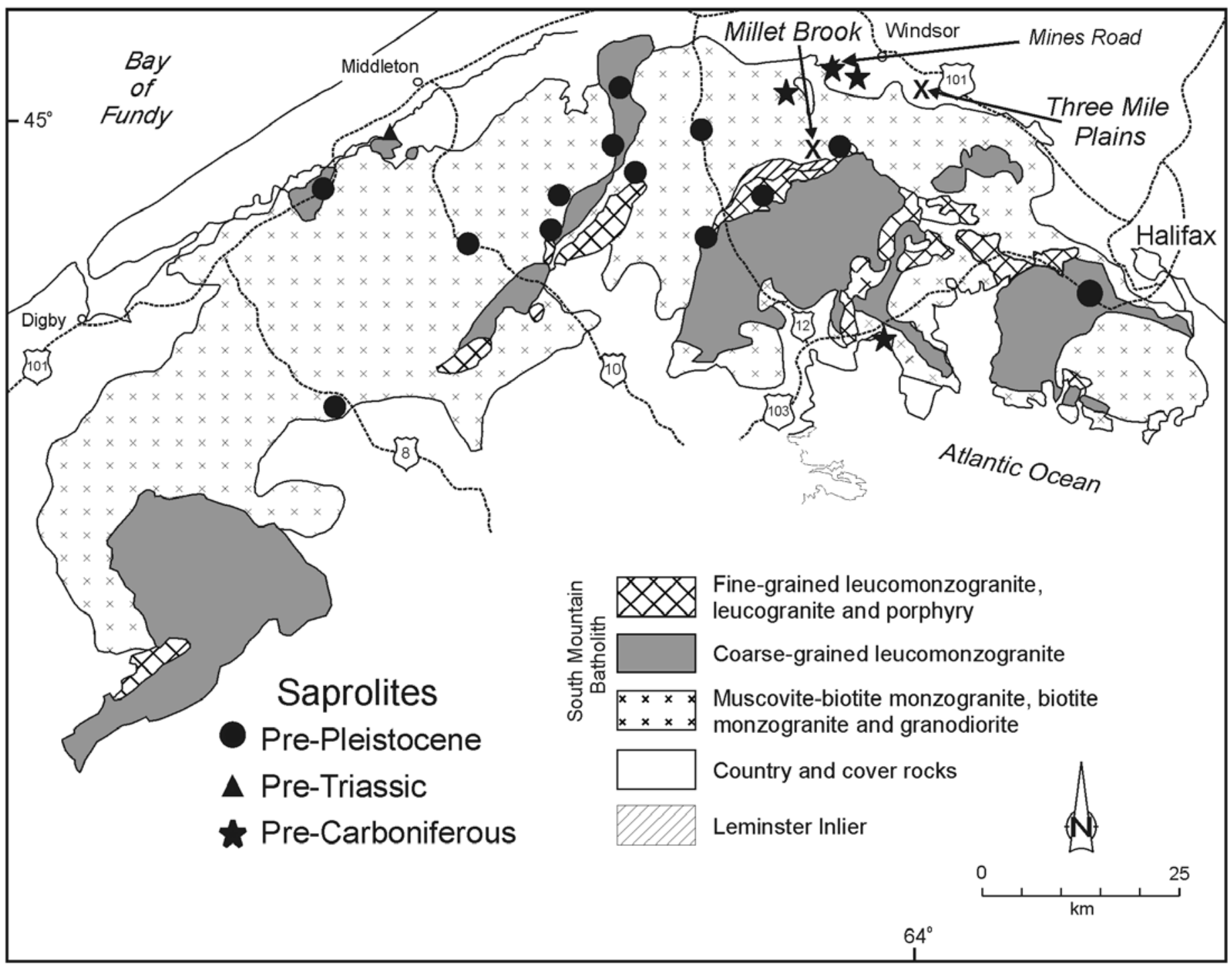

Fig. 3. Simplified geology map of the South Mountain Batholith and location of the Millet Brook and Three Mile Plains occurrences in relation to saprolites (after Ryan et al. 2005).

gin of the North American continent and represents the most outboard component of continent building in eastern North America (Keppie 1993; Schenk 1995). The terrane is characterized by the presence of a thick sequence of Cambrian to Early Ordovician slate and quartzite referred to as the Meguma Group or Supergroup. The Meguma Supergroup is locally overlain by Upper Ordovician to Early Devonian metasedimentary and metavolcanic sequences. The Cambrian-Early Devonian units of the Meguma terrane were intruded by Middle to Late Devonian granitoid plutons of the South Mountain Batholith (Keppie 1993; Williams 1995) which is the largest igneous mass in the Appalachian orogen. The granitoids can be grouped together into two stages of intrusion: (1) an older, mostly granodiorite and monzogranite stage and 2) a younger, mostly monzogranite, leucomonzogranite, and leucogranite stage (MacDonald et al. 1992) (Fig.3). Although the history of intrusion is complex, geochronological evidence indicates that all plutons were intruded and crystallized during a short time interval at ca. $380 \mathrm{Ma}$ (Clarke et al. 1997; Carruzzo 2003).

At numerous localities, Late Devonian-Carboniferous and/ or Triassic clastic sedimentary strata unconformably overlie the metamorphic and crystalline basement rocks. Poorly consolidated Cretaceous strata locally overlie these sedimentary rocks. Most of the material occurring at surface in southern Nova Scotia is unconsolidated Pleistocene glacial till (Finck and Stea 1995).

The Carboniferous strata partially cover, and therefore stitch together, the Meguma terrane and now-adjacent Avalon terrane to the north and form the Nova Scotian portion of the Maritimes Basin (Fig.1). Van de Poll and Ryan (1985) suggested that the Maritimes Basin should not be thought of as a single post-orogenic Carboniferous-Permian basin, but rather as a "composite basin" consisting of a group of interconnected fault-block basins and horsts, which at various times shared similar subsidence rates and strata. 


\section{STRATIGRAPHY}

The general stratigraphy of the Maritimes Basin in mainland Nova Scotia (Fig. 4) consists of a Late Devonian redbed and volcanic sequence referred to as the Fountain Lake Group, Late Devonian to Mississippian clastic fluvial-lacustrine rocks of the Horton Group, Mississippian marine evaporite, clastic-carbonate sequence of the Windsor Group, the fine-grained terrestrial clastic rocks of the Mabou Group, coal measures of the Cumberland Group, and late Carboniferous to Permian redbeds of the Pictou Group (Ryan et al. 1991)(Fig. 4). A Jurassic-Triassic basin (Fundy Basin) comprised of sandstone, shale, basalt, and minor limestone subsequently developed in the area surrounding the Bay of Fundy. During the Cretaceous, fluvial quartz sands and kaolin of the Chaswood Formation (Stea and Pullan 2001) were deposited throughout the Maritimes but only a few outliers have been preserved.

\section{Horton Group}

A multitude of formation names are applied to various Horton Group units in different regions of the Maritimes Basin (Fig. 5); in this paper we use the nomenclature from the type area (Bell 1929; Moore and Ferguson 1986) (Fig. 5). The Horton Group in this area hosts one of the best documented uranium roll-front occurrences, and consequently correlation of the Horton Group throughout the Maritimes Basin is important, because the uranium enrichment is, in part, controlled by stratigraphy. Hence, the distribution of correlative units with the potential for uranium enrichment has important economic and environmental implications. The Fountain

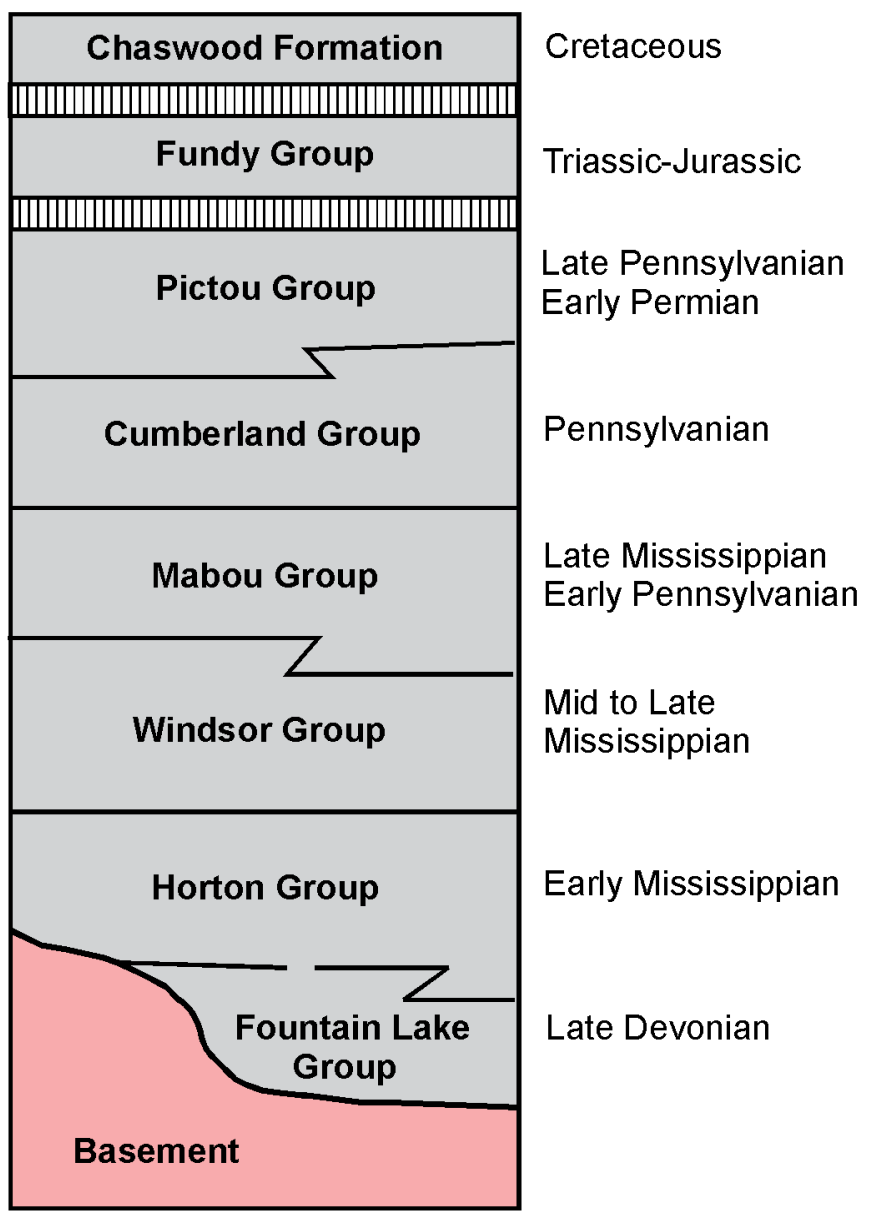

Fig. 4. General stratigraphy Maritimes Basin (after Ryan et al. 1991).

\begin{tabular}{|c|c|c|c|c|c|c|}
\hline This Paper & $\begin{array}{l}\text { Type Area } \\
\text { Bell (1929) }\end{array}$ & & $\begin{array}{l}\text { Type Area } \\
\text { artel and Gibling (1996) }\end{array}$ & $\begin{array}{c}\text { Cape Breton } \\
\text { Murray (1960) }\end{array}$ & $\begin{array}{c}\text { New } \\
\text { Brunswick } \\
\text { st. Peter (1993) }\end{array}$ & $\underset{\text { Knight (1983) }}{\text { Newfoundlanc }}$ \\
\hline $\begin{array}{l}\text { Upper } \\
\text { Horton } \\
\text { Group }\end{array}$ & Cheverie & 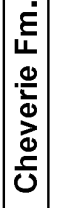 & $\begin{array}{l}\text { Cheverie } \\
\text { Formation }\end{array}$ & $\begin{array}{l}\text { Ainslie } \\
\text { Formation }\end{array}$ & $\begin{array}{l}\text { Bloomfield } \\
\text { Formation }\end{array}$ & $\begin{array}{l}\text { Spout Falls } \\
\text { Formation }\end{array}$ \\
\hline $\begin{array}{l}\text { Middle } \\
\text { Horton } \\
\text { Group }\end{array}$ & $\begin{array}{l}\text { Upper Horton } \\
\text { Bluff } \\
\text { Middle Horton } \\
\text { Bluff }\end{array}$ & 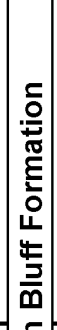 & $\begin{array}{c}\text { Hurd Creek } \\
\text { Member } \\
\text { Blue Beach } \\
\text { Member } \\
\text { Curry Brook } \\
\text { Member } \\
\end{array}$ & $\begin{array}{l}\text { Strathlorne } \\
\text { Formation }\end{array}$ & $\begin{array}{l}\text { Albert } \\
\text { Formation }\end{array}$ & $\begin{array}{l}\text { Friars Cove } \\
\text { Formation } \\
\text { Snakes Bight } \\
\text { Formation }\end{array}$ \\
\hline $\begin{array}{l}\text { Lower } \\
\text { Horton } \\
\text { Group }\end{array}$ & $\begin{array}{c}\text { Lower } \\
\text { Horton } \\
\text { Bluff }\end{array}$ & 호 & $\begin{array}{l}\text { Harding Brook } \\
\text { Member }\end{array}$ & $\begin{array}{l}\text { Craignish } \\
\text { Formation }\end{array}$ & $\begin{array}{l}\text { Memramcook } \\
\text { Formation }\end{array}$ & $\begin{array}{l}\text { Kennels } \\
\text { Brook } \\
\text { Formation }\end{array}$ \\
\hline
\end{tabular}

Fig. 5. Correlation of the Horton Group in Atlantic Canada. 
Lake Group locally underlies the Horton Group but in many areas, the Horton Group directly overlies pre-Carboniferous basement rocks. For example, in the type area near Windsor, Nova Scotia, Horton Group strata overlie metasedimentary rocks of the Meguma Supergroup or granitoids of the South Mountain Batholith.

\section{Lower Horton Bluff Formation}

The lower part of the Hoton Bluff Formation, the lowermost unit in the Horton Group, is an overall fining-upward sequence dominated by basin-margin conglomerate and a sandstonedominated, more basinward, facies. The unit is compositionally dependent on the lithologies of the adjacent basement source areas. For example, in areas underlain by the Meguma Supergroup, basal conglomerate of the Horton Group is composed primarily of quartz-pebble conglomerate derived from quartz veins that are ubiquitous in metasedimentary strata, whereas in areas flanked by granitic basement the basal conglomerate is typically arkosic granite-pebble conglomerate. The upper part of the unit is dominated by sandstone with carbonaceous quartz-rich litharenite and arkose inter- cross-stratified with subordinate grey siltstone and organic-rich shale. The finer grained rocks locally contain abundant plant debris. These strata are interpreted to have been deposited along the basin margins as locally derived alluvial fans that grade laterally and vertically into low sinuosity streams (Martel and Gibling 1996; Ryan 1998). A lacustrine influence in the unit is more evident toward the top of the sequence, suggesting that the streams ultimately emptied into a large inland lake in the central portions of the basin, with sandstone deposition occurring in distributary channels and lacustrine deltas (Ryan 1998; Ryan and O'Beirne-Ryan 2007).

\section{Middle and Upper Horton Bluff Formation}

The middle and upper Horton Bluff Formation comprises the middle part of the Horton Group. This interval consists of a grey, mainly fine-grained, coarsening-upward succession. The rocks include grey to black organic-rich shale, mudrock, oil shale, siltstone, and sandstone with thin carbonate and rare evaporite. Sandstone beds generally makes up less than $10 \%$ of the succession and are more numerous and thicker near the top of the coarsening-upward sequence. Plant debris, fish scales, and ostracods are locally very abundant. The thickness of the unit varies throughout the Maritimes Basin, from a few tens of metres near basin margin overlap areas, to in excess of $1200 \mathrm{~m}$ elsewhere (Howie and Barss 1975). The mean thickness of the unit is approximately $800 \mathrm{~m}$ based on numerous seismic reflection profiles throughout the Maritimes Basin. The middle and upper Horton Bluff Formation is stratigraphically equivalent to the black albertite-bearing shale and quartz-rich sandstone of the Albert Formation in New Brunswick, which are the source and reservoir rocks of the small but long-producing oil and gas field at Stoney Creek and the recent gas discoveries in the Sussex area (Keighley and St. Peter 2006). In the lower part of the succession the sandstone beds rarely exceed $1.2 \mathrm{~m}$ in thickness; however, at the top of the unit multistoried-multilateral channel sandstone bodies can attain thicknesses up to approximately $30 \mathrm{~m}$. Sandstone in the unit is typically quartz-rich and exhibits significant porosity and permeability.

The presence of fresh water fish, plant debris, and thin pedogenic carbonate layers suggests that the fine-grained beds were deposited in a lacustrine environment; however, the presence of thin horizons with glauconite grains, marine-affinity bivalves, arenaceous foraminifera, and one specimen of a trilobite (Weir 2002; Tibert and Scott 1999) suggest a distal marine influence (Martel and Gibling 1996; Ryan 1998; Tibert and Scott 1999). The fine-grained unit is therefore interpreted to represent lacustrine sedimentation in a large inland lake that covered most of the Maritimes Basin during Horton Group deposition, and which had distal marine influences. Sandstone sedimentation occurred in lacustrine sandstone deltas, distributary channels, and beach sand areas marginal to and interfingering with the lake sediments. The lake sediments were subsequently incised by meandering and low sinuosity streams (Martel and Gibling 1996). Bell (1929) referred to these quartzrich sandstone beds as the "glass sand unit" because these rocks were historically used to manufacture glass. The presence of multicolored shale near the top of the sequence attests to the general drying up of the inland lake (Ryan 1998).

Thickness variations in the unit are probably the result of two factors. One contributing factor was significant irregularity on the surface of the basin after the deposition of the lower Horton Group that is inferred from tops of formation contour maps (Quarch et al. 1979). The irregularities in this surface are interpreted as reflecting the underlying basement structural features. It has been demonstrated that within the type area of the Horton Group, the middle Horton Bluff Formation accumulated in depressions and that the unit thins dramatically over basement ridges draped by thin lower Horton Group sediments. The net result is a general smoothing out of the contours to top of formation for the subsequent Horton Group units. The second factor controlling the thickness of the unit is a pre-Cheverie Formation erosional episode. The upper contact of the Horton Bluff Formation is almost everywhere an angular unconformity with the overlying Cheverie Formation; thus the angle of tilting of the Horton Bluff Formation and the extent of erosion also contributed to thickness variations. The occurrence of low-angle thrusts and bedding plane displacements in this unit are common in most sub-basins and, consequently thickness estimates are often overestimated. The carbonaceous nature of these fine-grained strata within the sandstone-dominated Horton Group makes them a focal point for compression-related tectonic dislocations (Quarch $e t$ al. 1979; Teniere et al. 2005).

\section{Cheverie Formation}

Deposition of the Cheverie Formation, the uppermost part of the Horton Group, corresponded with a sudden shift from the relative tectonic quiescence of lake sedimentation 
in the Horton Bluff Formation to rapid, coarse-grained sedimentation related to uplift of the adjacent basement areas and rapid subsidence of the basin (Martel and Gibling 1996). Thick arkosic sandstone-dominated successions are typical of the Cheverie Formation, especially where the basin is flanked by granitic basement areas. Basin-margin conglomerate is common and locally very thick. The strata deposited in the overbank environment during this interval are typically low in organic material and are typically green or red, contrasting with the grey fine-grained strata prevalent in the older Horton Group units. The succession forms a generally fining upward sequence whereas the proportion of sandstone to mudrock decreases up section. The more central portions of the basin or sub-basin appear to have a sequence dominated by thinner sandstone beds at the base that grade upward into a mainly fine-grained sequence of predominately red siltstone and mudrock (Quarch et al. 1979). Locally, younger successions of conglomerate, sandstone, siltstone, shale, and minor limestone (and rarely gypsum) occur at the top of the Horton Group. In these cases deposition continued within basinal depressions prior to the onlap of the Windsor Group, with only minor erosion taking place along the basal Windsor Group unconformity.

\section{Correlation of the Horton Group}

Regional correlation of the Horton Group is pinned on two strong marker horizons: (1) widespread lacustrine strata of the Horton Bluff Formation and probably equivalent Albert, Strathlorne, and Snakes Bight-Friars Cove formations (Fig. 5), and (2) the basal Windsor Group carbonate representing the basin-wide transgression of the Windsor Sea. These two horizons are lithologically distinct and widespread. On the basis of palynology Utting et al. (1989) also suggest that these horizons are good chronostratigraphic markers.

Comparisons of the various local formations show a remarkable consistency of the overall succession across the ba$\sin$. The tripartite subdivision of the Horton Group is tenable, although local variations in lithology are to be expected given the variation in local source areas. In many areas in the basin, an angular unconformity separates the base of the Cheverie Formation from underlying either Horton Bluff Formation or pre-Horton Group Devonian strata. Martel and Gibling (1996) and Hamblin and Rust (1989) noted the consistency of the three-stage stratigraphy of the Horton Group in the Maritimes Basin.

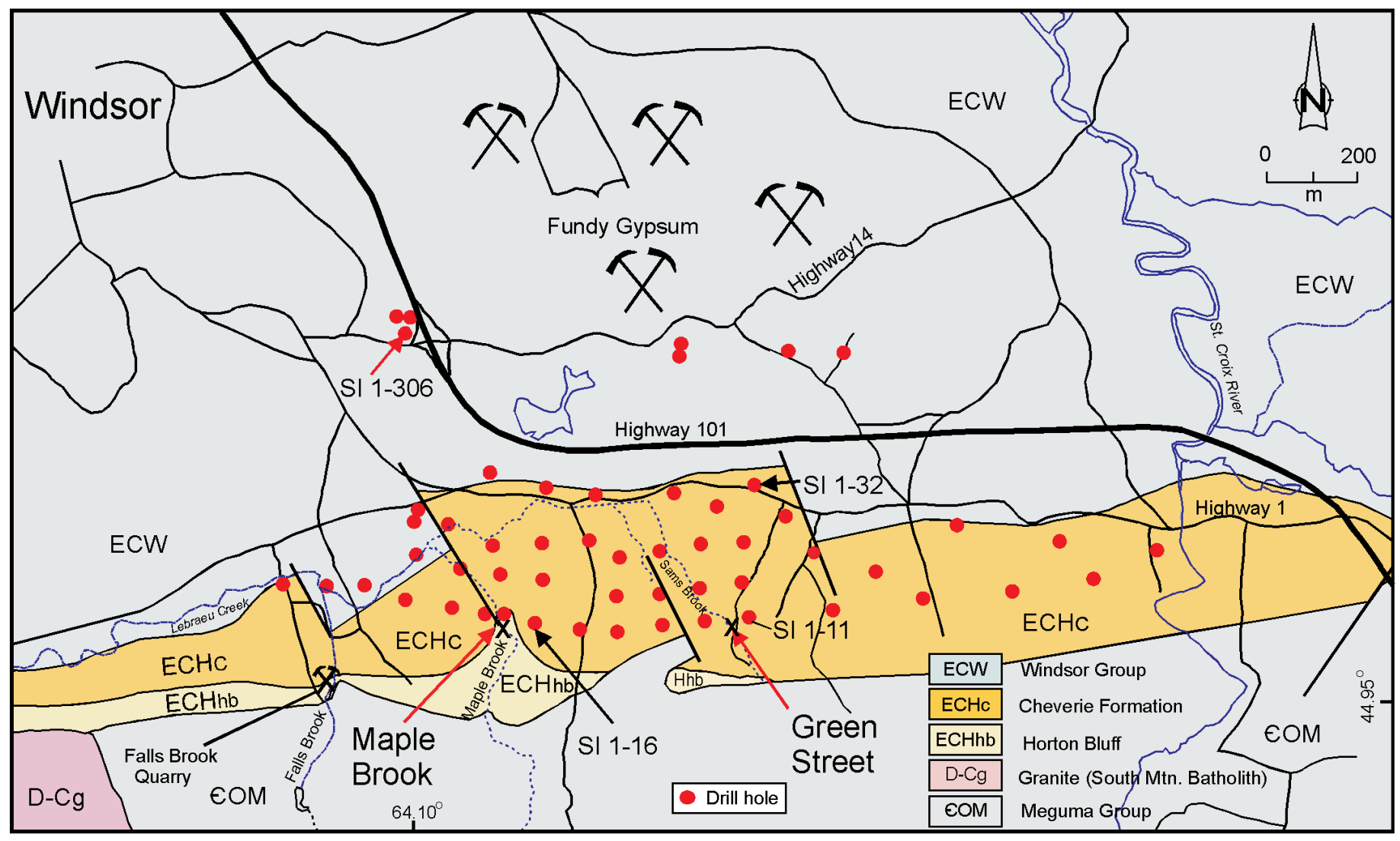

Fig. 6. Geology map of the Three Mile Plains area near Windsor, Nova Scotia (after Ryan and O’Beirne-Ryan 2007). 


\section{URANIUM OCCURRENCES}

In the area near Windsor, Nova Scotia, numerous uranium occurrences have been reported, with the most notable being at Three Mile Plains, where Saarberg Interplan Canada Ltd. drilled over forty diamond-drill holes from 1979 to 1981 (Fig. 6). Significant uranium enrichment is restricted to the upper Horton Bluff Formation "glass sand unit "and an arkosic sandstone unit at the base of the Cheverie Formation. These units lie immediately below and above, respectively, the unconformity between the Horton Bluff and the Cheverie formations. The unconformity is also the site of a reduction-oxidation boundary, with red and green strata above the unconformity and grey, organic-rich strata below. Uranium occurrences associated with these strata are roll-front type deposits but are further divided herein into two types: (1) carbon-pyrite quartz sandstone type hosted by the Horton Bluff Formation and (2) hematite arkosic sandstone type hosted by the Cheverie Formation.

\section{Carbon-Pyrite Quartz Sandstone Type}

This deposit type is hosted by the "glass sand unit" of Bell (1929) which occurs near the top of the Horton Bluff Formation (Fig. 5). This unit is the Hurd Creek Member of the Horton Bluff Formation in the terminology of Martel and Gibling (1996). The unit is dominated by coarse- to finegrained quartz-rich sandstone. The porosity of the sandstone ranges from $9-15 \%$ with permeability between 5 and $250 \mathrm{mD}$ (millidarcys). The most common bedforms are low-angle forsets and shallow trough cross-stratification. Multilateral, multistoried channel sequences form sandstone sheets up to $30 \mathrm{~m}$ thick. The bases of the individual channels commonly consist of coarse pebbly quartz sandstone that has abundant plant detritus as lag material. Mica is noticeably absent in the sandstone and feldspar is rare; however, where it does occur it exists as K-feldspar that has been intensely kaolinized. Thin interbeds of grey cross-laminated siltstone and shale occur within the sandstone bodies and the sand bodies are underlain and overlain by lacustrine grey shale and siltstone. The environment of deposition for the unit is interpreted to be in distributary channels in a lacustrine delta setting (Martel and Gibling 1996). Ryan et al. (2005) suggested that the quartz-rich nature of the sandstone is the result of a monomineralic source area rather than a unique environment of deposition. These authors postulated that the "glass sand unit" is made up of detritus derived from the upper levels of the pre-Carboniferous paleosaprolite in which the intensity of weathering resulted in only kaolinite and quartz remaining.

Uranium occurs as very fine-grained uranium oxides associated with pyrite that is inextricably related to carbon-rich horizons within the sandstone and shale. The presence of these reductants changes the valence state from the soluble $\mathrm{U}^{6+}$ to the insoluble $\mathrm{U}^{4+}$ state and deposits the uranium at or near the reducing pyrite and/or carbon-rich sites. The uranium enrichment is related to reduction-oxidation fronts in the sandstone; however, the paucity of iron-bearing minerals and the subsequent reduction that affected the sandstone after uranium mineralization obscures the classic red to grey boundaries typically associated with this type of mineralization. There are, however, very subtle differences in the colour and carbon content of the oxidized versus primary-reduced sandstone beds. The oxidized sandstone appears to be bleached to a very light buff to light greyish-tan and only the larger plant fragments are preserved in the permeable sandstone. In contrast, the down-dip (reduced) sandstone is light to medium grey and has abundant fine plant debris preserved, in addition to the large fragments. Evidence for the redox front is often more clearly manifest in the nature of the pyrite in the sandstone beds, with finer disseminated pyrite representing the rereduced pyrite of the once reddened up-dip sandstone portion of the roll-front, and the well-formed diagenetic crystals of pyrite representing the down-dip portions. Galloway and Kaiser (1980) suggested that if similar deposits in south Texas were re-reduced that they would be classified as Colorado Plateau Trend-type uranium deposits. The deposits in the Horton Bluff Formation have been re-reduced and therefore share many characteristics with the deposits of the Colorado Plateau, even though they probably formed as the more classic Texas-style roll-front deposits.

The best documented occurrence of the carbon-pyrite quartz-sandstone redox uranium enrichment is at Maple Brook in the Three Mile Plains area (Fig.6), where bedrock samples from trenches contained up to $555 \mathrm{ppm}$ uranium (Morse and Harder 1979). In Saarberg Interplan's drill hole SI 1-16, adjacent to the trench anomaly, it is apparent that the uranium is tied up primarily as roll-front tails (Fig. 7) in the organic-rich shale above and below the sandstone indicating that the rollfront has passed beyond this intersection. Gamma logs of SI 1-16 and adjacent drill holes exhibit the classic double spike anomalies (tails) that typically occur up-dip of the roll-fronts. Only rare examples exist of the classic broad anomaly within the sandstone ahead of the roll-front mineralization, in the remote seepage zone. The uranium is associated with smokey quartz and pyrite; however, the grey colour of the sandstone makes identification of the smokey quartz horizons tedious. As the uranium concentrations rarely exceed $500 \mathrm{ppm}$, these occurrences are probably sub-economic, however, they do have significant environmental implications. It should be noted that Morse and Harder (1979) found that the bedrock contained less uranium than predicted from the radioactivity measurements suggesting disequilibrium, as daughter products have been chemically separated from their parent. This disequilibrium is consistent with re-oxidation of uranium, resulting in remobilization of the uranium from the site of its daughter product radium, which is less soluble than uranium, therefore leaving radium behind as the roll-fronts migrate. Such disequilibrium implies active uranium mobilization in the recent geological history of the rocks. Oxidation of uranium in an active system in the presence of groundwater results in up- 


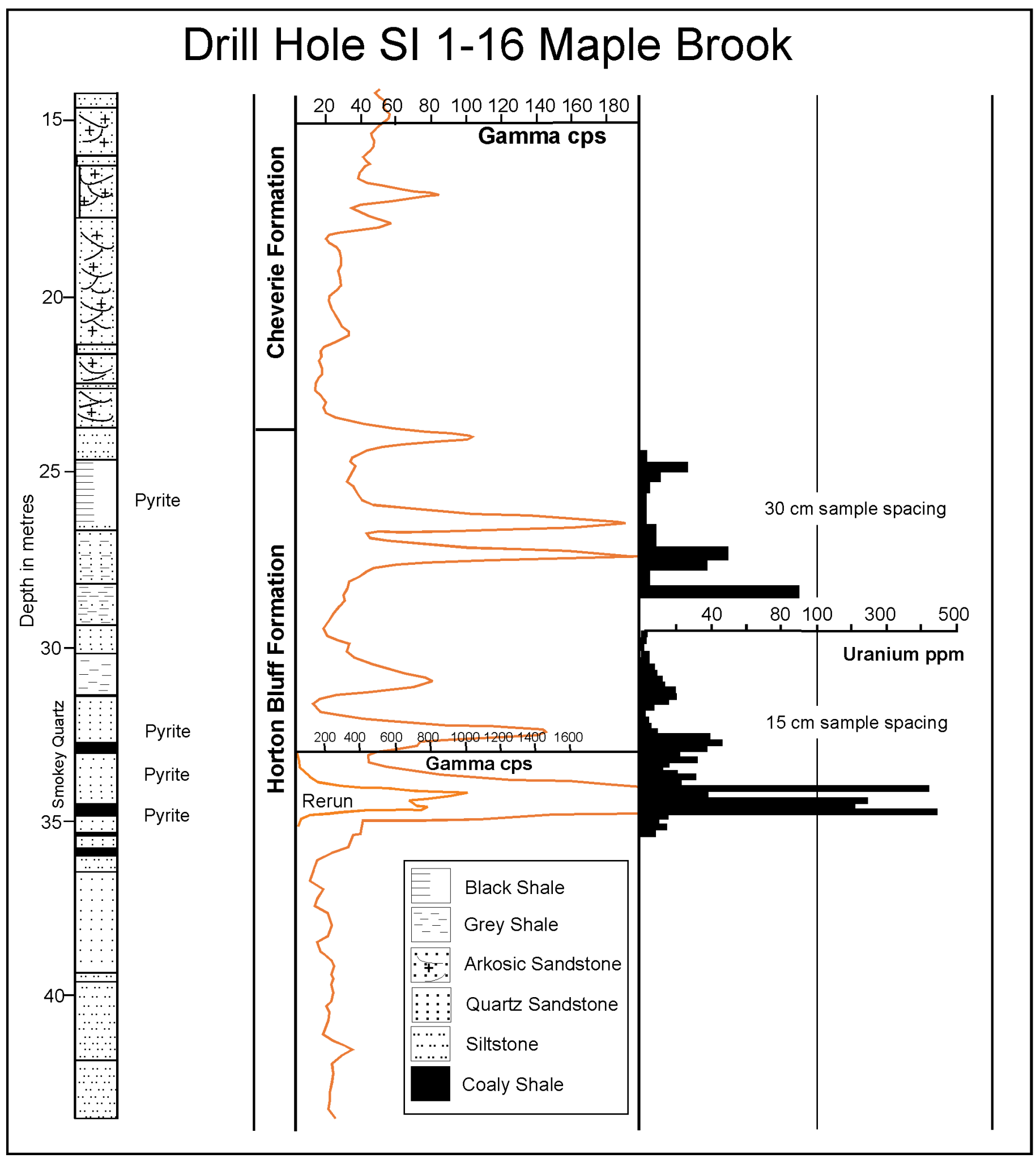

Fig. 7. A portion of the drill hole SI 1-16 drilled into the uranium occurrence at Maple Brook, Three Mile Plains. Note the double spike gamma anomalies associated with the organic rich fine-grained intervals. 
take of uranium in the groundwater. Health Canada guidelines recommend upper limits of $0.02 \mathrm{mg} / \mathrm{l}$ uranium in drinking water. In an active system with elevated uranium, such as that in the Windsor area, the potential is high for uranium levels in groundwater to exceed the $0.02 \mathrm{mg} / \mathrm{l}$ guideline.

\section{Hematite Arkosic Sandstone Type}

Uranium occurrences in the Cheverie Formation are restricted to the lower sequence of thick arkosic sandstone, siltstone, and pebbly conglomerate. The arkosic sandstone is best described as granite wash, with feldspar representing up to $25 \%$ of the rock. The sandstone occurs as multilateral, multistoried channel sand sheet bodies up to $20 \mathrm{~m}$ thick. The coarse-grained sandstone generally exhibits only crude fining-upward cycles and the sandstone to siltstone/shale ratio is approximately 8 to 1 in the Three Mile Plains area. The most common bed forms in the sandstone are large scale (up to $10 \mathrm{~m}$ wide) trough crossbeds. The sandstone is variably micaceous with flakes of both biotite and muscovite. Carbonaceous plant material is present but much less abundant than in the sandstone of older Horton Group strata. The overbank siltstone and mudrock are generally red or green, although minor grey beds occur. The green and grey fine-grained beds are commonly mottled with red. Rip-up clasts of the fine-grained overbank strata, up to $5 \mathrm{~cm}$ in diameter, are commonly incorporated into the arkosic sandstone. The lower sandstone-dominated portion of the Cheverie Formation has been interpreted as a lower alluvial fan-braided stream deposit (Ryan 1998).

In drill core, pyrite and to a lesser extent marcasite occur as amorphous blebs near the uranium-rich zones. Minor disseminated pyrite occurs as fine crystals in unmineralized grey and green mudrock. Immediately adjacent to zones of uranium-enrichment some of the sulfides have been oxidized to hematite. In outcrop at the Green Street uranium occurrence (Fig. 8), most of the sulfides have been oxidized and hematite staining is pervasive (Fig. 9). The persistence of iron oxides near areas of uranium enrichment can also be observed in diamond-drill hole SI 1-11 (Fig. 10) adjacent to the Green Street occurrence. In addition to hematite surrounding the iron sulfides, iron and titanium released from weathering of biotite form $\mathrm{Fe}$-Ti oxides that migrate to grain boundaries and along internal fracture surfaces. The presence of uranium enrichment associated with the oxidized biotite is evident in the fission track distribution in the altered grains (cf. Zielinski et al. 1983) (Fig.11).

In the pre-Carboniferous saprolite, biotite has been completely weathered to clay and Fe-Ti oxides to within a few centimetres of the fresh granite. The arkosic nature of the sandstone in the Cheverie Formation, with fresh K-feldspar and variably weathered biotite and plagioclase, indicates that the source area was only incipiently weathered, in contrast to the intensely weathered source area of the "glass sand unit" of the Horton Bluff Formation. Reddening of the K-feldspar grains and the smoky grey appearance of quartz grains near the uraniumenriched zones are consistent with mineral alteration by irradiation(Baranov 1959; Weil 1975; Gabelman 1977) (Fig. 9).

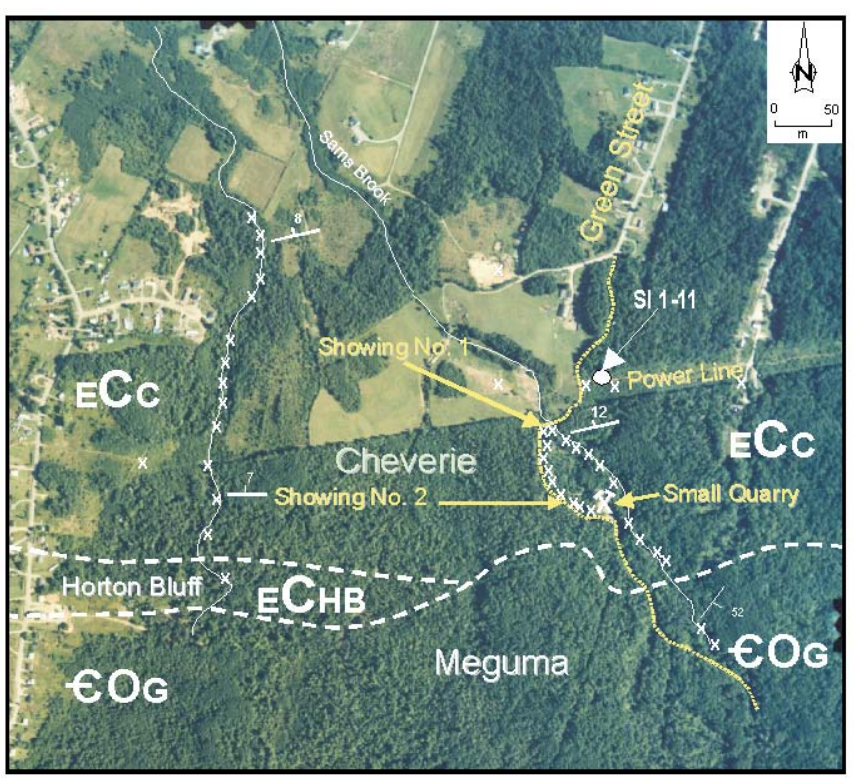

Fig. 8. Detailed location and geology map of the Green Street uranium occurrence. (see legend on Figure 6).

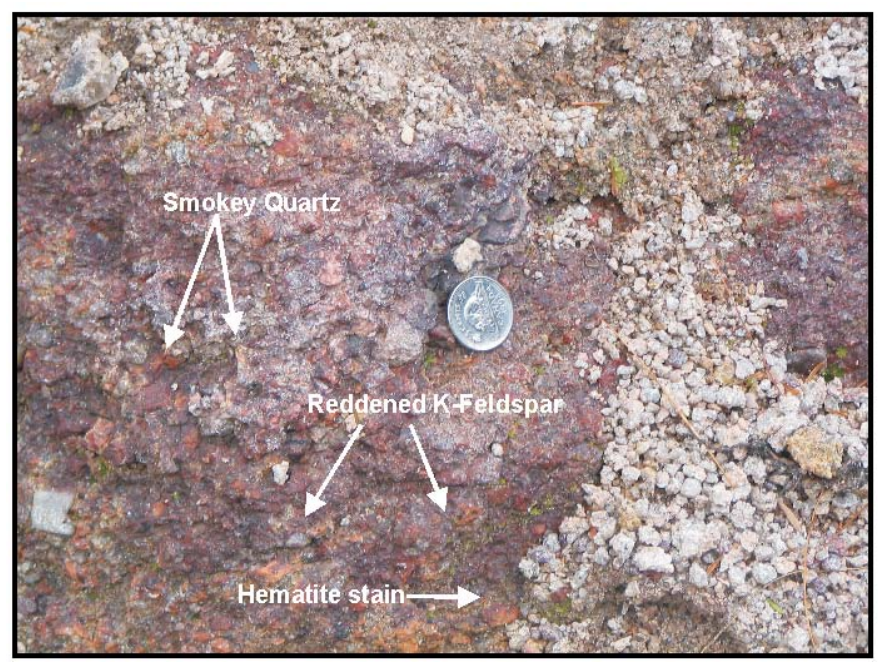

Fig. 9. Photograph of the arkosic sandstone at the Green Street uranium occurrence, note the presence of hematite+ limonite, smokey quartz, and the reddened k-feldspar.

Kaolinization of the feldspar has also occurred in the oxidized beds, although it primarily involved the plagioclase. Above and below the uranium-enriched sandstone beds, the arkosic units have abundant patchy dolomitic cement, whereas within the mineralized zones carbonate occurs primarily as thin dolomitic-calcite veins along fractures. Harshman (1968) documented the association of carbonates with roll-front deposits in the Shirley Basin in Wyoming and Galloway and Kaiser (1980) indicated that calcite cementation is one of the last stages of uranium paragenesis in the south Texas deposits. Although most of the fine-grained beds in the Cheverie Formation in the Windsor area are green or red, siltstone beds near the mineralized horizons are typically grey. Their grey colour could 


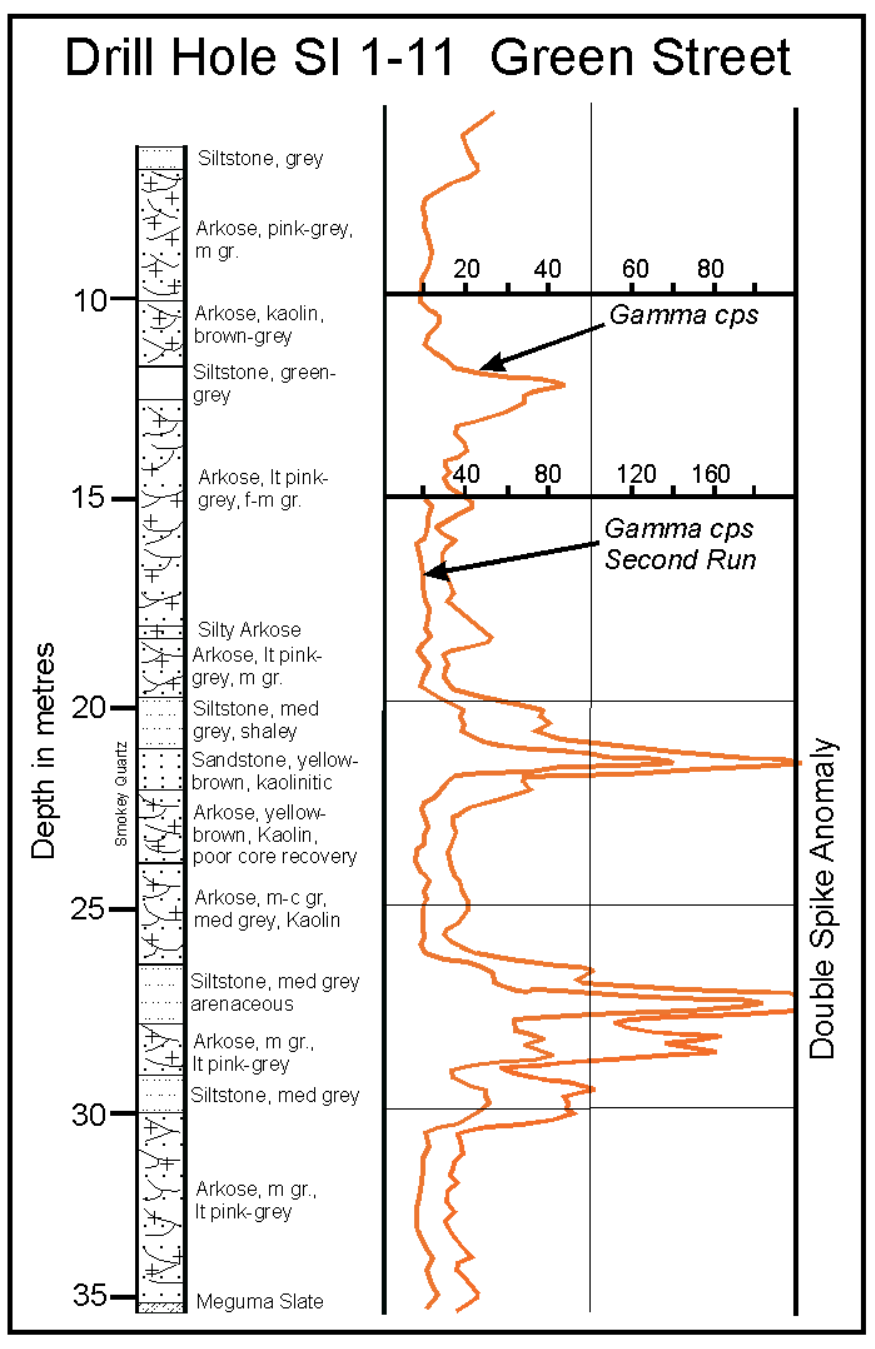

Fig. 10. A portion of the drill hole SI 1-11 at the Green Street uranium occurrence; note the classic double spike anomaly in the gamma log. Abbreviations: $f=$ fine, $m=$ medium,$c=$ coarse, $\mathrm{gr}=$ grained, $\mathrm{lt}=$ light, med $=$ medium (refers to shade of colour).

indicate the presence of organic carbon that would potentially act as a reductant, or alternatively, may reflect introduction of $\mathrm{H}_{2} \mathrm{~S}$ derived from underlying hydrocarbon source rocks in the Horton Bluff Formation prior to the uranium mineralizing event. The lack of organic matter in most south Texas deposits suggested to Goldhaber et al. (1978) that migration of $\mathrm{H}_{2} \mathrm{~S}$ up fault planes into the sandstone host was a necessary precursor to the roll-front mineralization.

Like the occurrences in the Horton Bluff Formation, the roll-front nature of the uranium mineralization in the Cheverie Formation is also evident from the characteristic double spike gamma ray anomalies shown in drill hole SI 1-11 (Fig. 10). The gamma $\log$ for SI 1-306 shown in Figure 12 also exhibits excellent examples of these features in two stacked sandstone bodies, a result of differential migration due to permeability variations.

For example at depths of $245 \mathrm{~m}$ and $251 \mathrm{~m}$ the double spike gamma anomaly signature, similar to that observed in drill hole

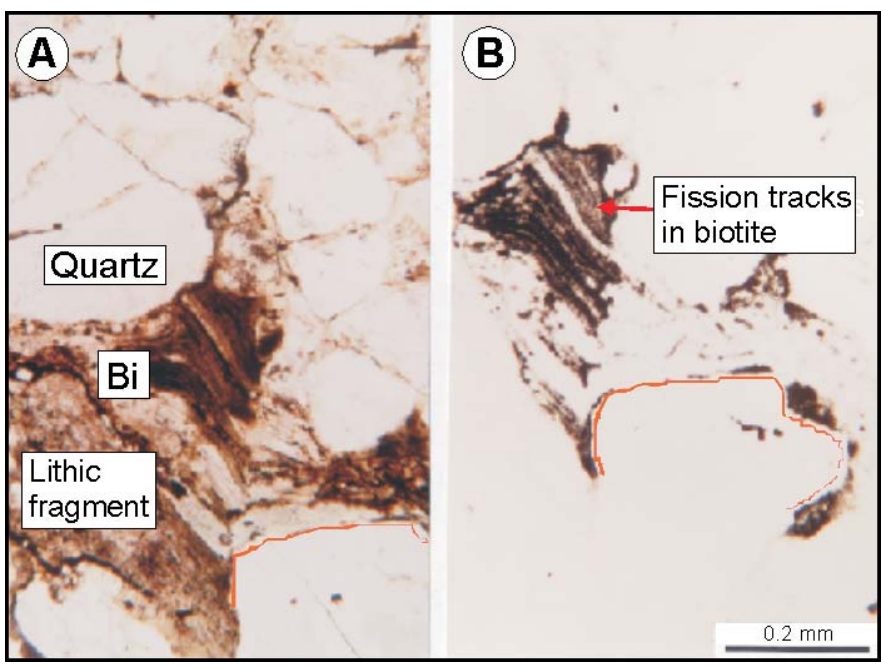

Fig. 11. Plane light photomicrograph of arkosic sandstone from the Green Street occurrence. (A) Quartz, lithic fragment and biotite (Bi). The outline (in red) on grain boundary in A corresponds with the grain boundary on B. (B) Fission tracks created by irradiating sample A. The darkest areas represent the highest concentration of uranium. Note that the uranium is most abundant in the biotite grain and that it occurs along planes of weakness in the partially weathered biotite.

SI 1-11, can be seen at the top and bottom of the arkosic sandstone interval in the upper part of the hole (Fig.12). The peaks in SI 1-306 contain between 150 and 380 ppm uranium over 30 - to $90-\mathrm{cm}$ intervals, with minimal enrichment of uranium in the central part of the sandstone unit (Fig.12). These peaks are interpreted to represent remnant uranium enrichment left behind in roll-front tails, occurring primarily at the contact with reducing fine-grained beds. Deeper in the hole at the interval between $263 \mathrm{~m}$ and $275 \mathrm{~m}$, multiple broad peaks on the gamma log correspond to elevated uranium in the central part of a sandstone unit, rather than at its upper and lower extremities as in the shallower double-spike peaks (Fig.12). Several metres of sandstone consistently range from 15 to $100 \mathrm{ppm}$ uranium and $30 \mathrm{~cm}$-wide spikes range from 520 to $837 \mathrm{ppm}$ uranium. These areas of uranium enrichment are interpreted to represent a proximal seepage zone, with the drill hole intersection penetrating immediately in front of the main portion of the roll-front (Fig.12).

Uranium enrichment in drill hole SI 1-32 (Fig. 13), located down dip from the Green Street occurrence and drill hole SI 1-11, occurs within the middle part of a thick sandstone unit (between 35-46 m), and again the gamma logs exhibit the classic double-spike anomaly in relation to the overlying and underlying fine-grained beds. This situation contrasts with the missing lower spike in the deeper uranium-rich interval in drill hole SI 1-306. SI 1-32 is interpreted as penetrating the sandstone just behind an asymmetric roll-front (Fig. 13).

The gamma log characteristics represent the most useful information for the determination of the location of drill holes 


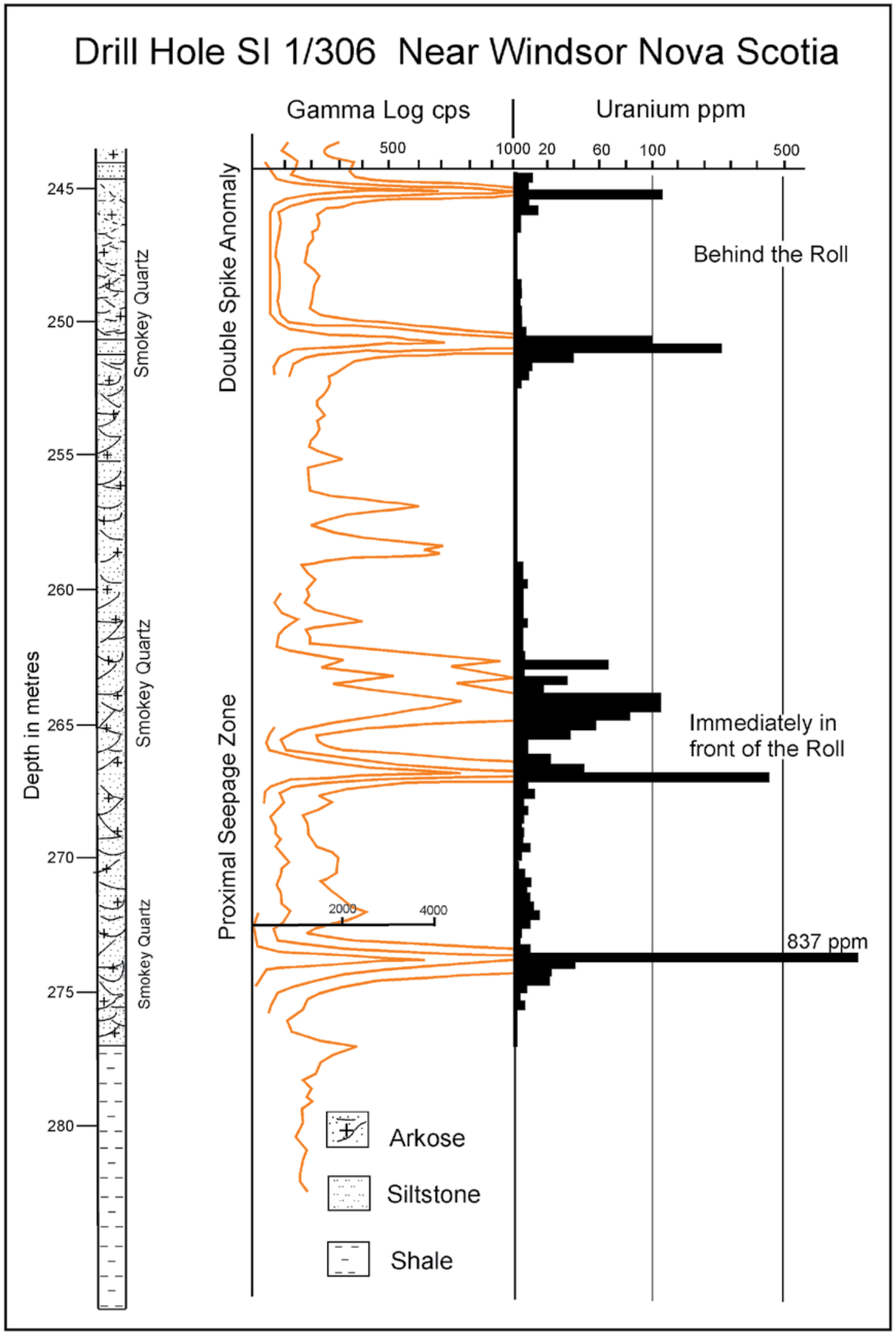

Fig. 12. A portion of the log for Saarberg Interplan Canada's drill hole SI 1-306, near Windsor, Nova Scotia. Note that the upper mineralized intervals represent a classic behind the roll-front double spike anomaly, whereas the lower mineralized interval has broad anomalies within the sandstone unit and represents a proximal seepage zone. 


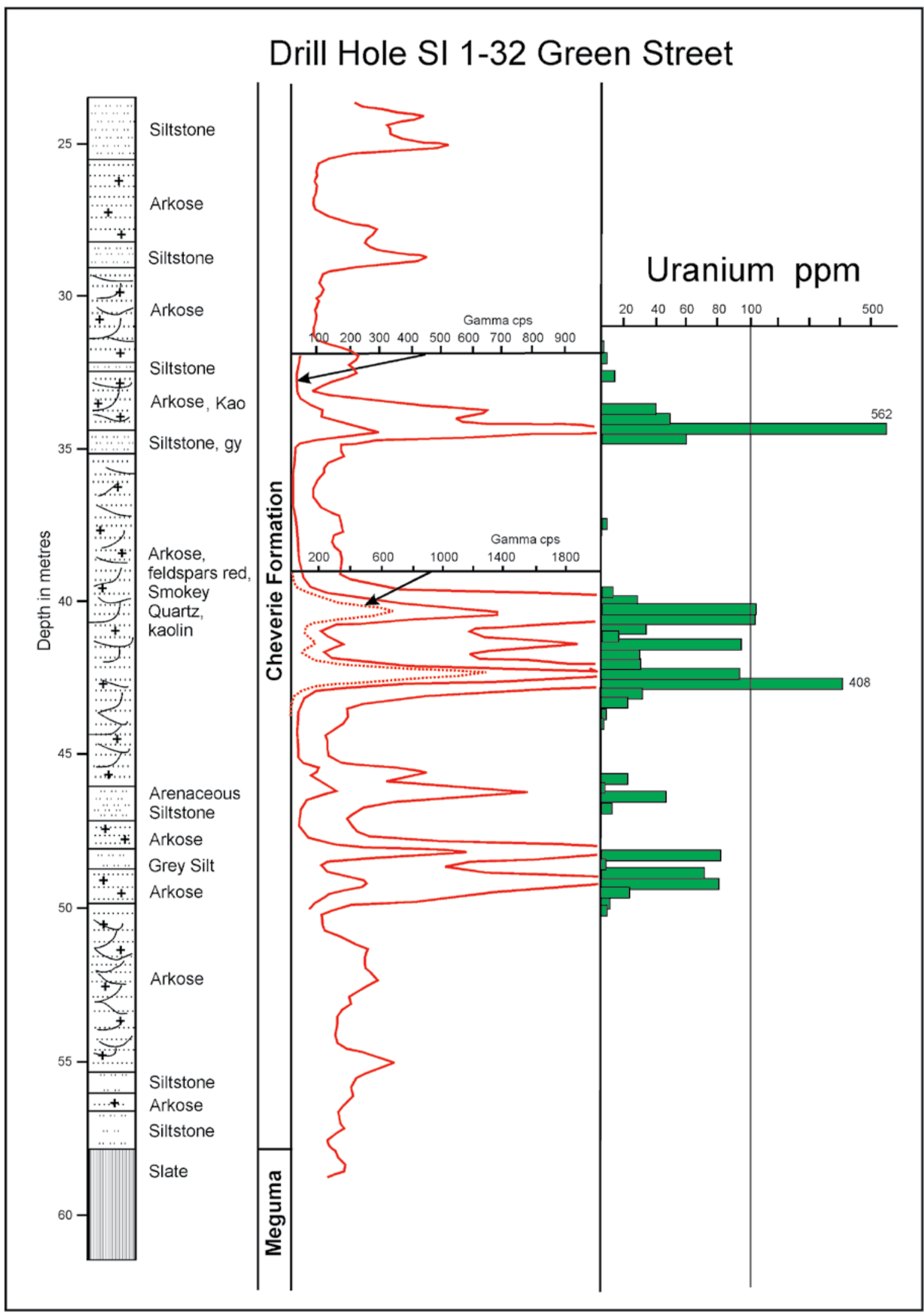

Fig. 13. A partial log of drill hole SI 1-32 down dip of the Green Street uranium occurrence. The mineralized interval in this hole has a double spike and a central sandstone anomaly as well, indicating that the intersection is immediately behind the roll-front. Abbreviations: Kao = kaolin, gy = grey. 


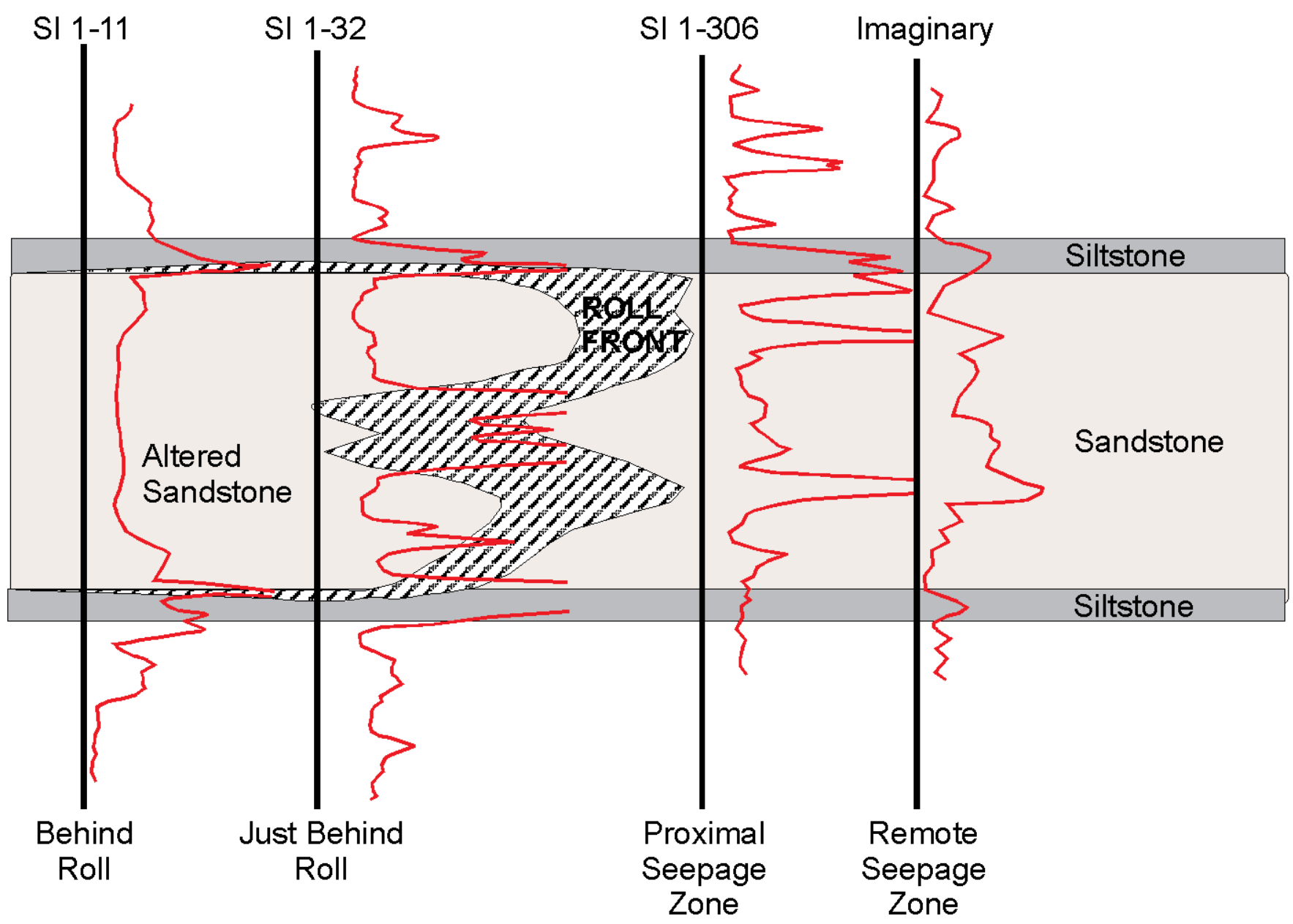

Fig. 14. This figure is a model of the expected gamma log responses relative to a hypothetical roll-front deposit. Gamma logs for drill holes 1-11, 1-32 and 1-306 are used to postulate the position of the hypothetical roll-front. Note that minor adjustments of the depth scale to accommodate the diagram but the gamma intensity scales are approximately equal. The vertical line on the extreme right of the diagram is an imaginary drill hole showing the expected gamma log response for the remote seepage zone in front of the roll front as Saarberg Interplan drilling was predominantly up dip of the rollfronts, therefore did not penetrate this zone.

in relation to the roll-front. In order to better illustrate the gamma log responses at various locations relative to the rollfronts a model was constructed using portions from some of the gamma logs from the Saarberg drilling (Fig. 14). Figure 14 is not a cross section, but rather a diagram of a hypothetical roll-front and the expected gamma log characteristics. Care must be taken to make sure that the comparisons as to position of the drill holes in relation to any particular roll-front are restricted to an individual sandstone aquifer. In order to construct a true cross section, detailed stratigraphic correlation of individual sandstone packages in the subsurface would be essential.

\section{SAPROLITES AND URANIUM ENRICHMENT}

In the Maritimes Basin, direct correlation appears to exist between uranium enrichment in the basement rocks and the abundance of uranium occurrences in the overlying and adjacent basin-fill strata (Fig. 1). It is not surprising, therefore, that the majority of the uranium showings in the Horton Group occur in the Windsor area of the Maritimes Basin. Paleocurrent data from the Horton Group in the Windsor area indicate a predominantly northwesterly paleoflow into the basin (Quarch et al. 1979). These data are consistent with contributions to the basin-fill material from the uranium-enriched areas near Millet Brook and New Ross in the South Mountain Batholith (Chatterjee and Muecke 1982). Gableman (1977) pointed out that granitoids adjacent to sandstone-hosted uranium districts rarely exhibit evidence of uranium depletion and argued that the granitoid rocks are unlikely to be sources of uranium in such deposits. His premise was that uranium is too difficult to leach from the granitoid rocks because of their lack of permeability. This statement may be valid for fresh granitoid highland areas adjacent to other roll-front uranium districts; however, it is not the case in Nova Scotia where deep weathering occurred 


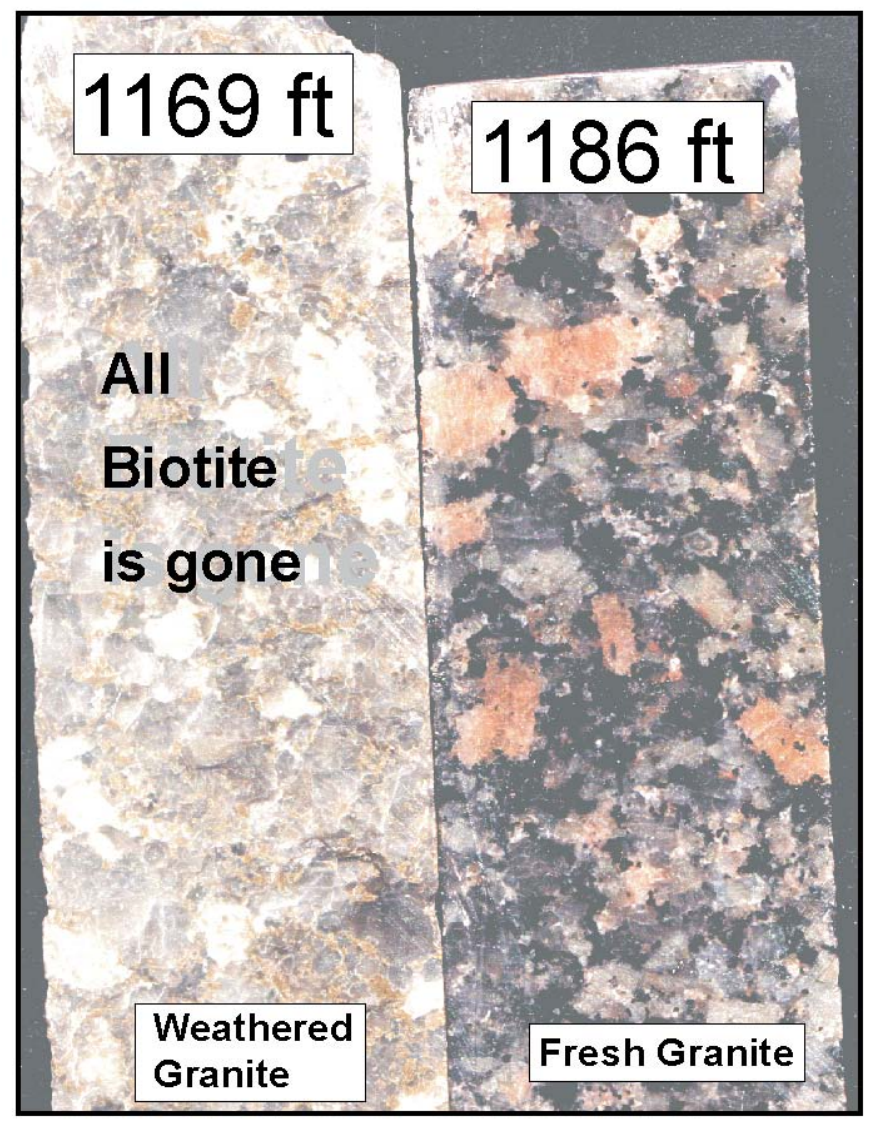

Fig. 15. Photographs of the paleosaprolite and parent unweathered granite underlying the Horton Group from a drill hole $4 \mathrm{~km}$ east of the Three Mile Plains area. Note that the granitic texture is intact; however, all of the feldspar grains are altered to kaolinite and biotite has been completely weathered out.

prior to the deposition of the basin-fill strata. O'Beirne-Ryan and Zentilli (2003) demonstrated the presence of pre-Carboniferous paleoweathered horizons on the South Mountain Batholith in the area adjacent to Three Mile Plains (Fig. 3). The age of these saprolite occurrences is constrained by their relationship with overlying lower Horton Bluff Formation strata in several drill holes (O'Beirne-Ryan and Zentilli 2003). The pre-Carboniferous weathered profiles found in this area differ in appearance from younger saprolites and represent the oldest preserved weathering event in the region (O'Beirne-Ryan and Zentilli 2003). The pre-Carboniferous paleoweathered surface has been re-lithified as a result of subsequent burial by as much as $5 \mathrm{~km}$ of Carboniferous sedimentary strata (Ryan and Zentilli 1993). This re-lithification resulted in an indurated rock of granite-like texture; however, on closer examination it is clear that biotite is absent in all but the least weathered material (Fig. 15) and that the feldspars have been extensively kaolinized. O'Beirne-Ryan and Zentilli (2003) pointed out that many of these horizons no longer exhibit isovolumetric weathering and therefore are no longer "saprolites" senso stricto. Lidmar-
Bergstrom et al. (1997) described similar re-lithified saprolites from paleosurfaces in Sweden ranging in age from Cambrian to Cretaceous.

Pre-Carboniferous weathering has some interesting implications with respect to exhumation of the South Mountain Batholith. The circa 380 Ma batholith must have been exhumed from 8-12 km depth and exposed for a sufficient time for the saprolite to develop, before $355 \mathrm{Ma}$, the age of the overlying strata. Similar pre-Carboniferous saprolites also occur in south-central Cape Breton Island, Nova Scotia, and in southeastern New Brunswick, suggesting a regional scale pre-Carboniferous weathering event (Ryan et al. 2005).

Most uranium in unmineralized granitoid rocks is present in insoluble minerals such as zircon and apatite; however, approximately $30-40 \%$ of the uranium is contained in biotite, feldspar, and other grains that are unstable under severe weathering conditions. It is noteworthy that the biotite, which contains significant uranium (Fig. 11), has been completely altered in the upper portions of the pre-Carboniferous paleoweathered horizon (Fig. 15). Similarly, the feldspars in the upper portions of the profile are replaced by kaolinite. Therefore, it is logical to assume that the weathering process liberated significant quantities of uranium. Uranium can also enter into the basin strata as detrital grains of uranium-rich minerals. In the paleoweathered profiles biotite that has not been completely weathered still exhibits significant mineralogical changes within the grains, resulting in uranium being more susceptible to leaching following incorporation into the basin-fill sandstone.

Chatterjee and Muecke (1982) noted that uranium is depleted in near-surface samples in the New Ross area of the South Mountain Batholith, which they attributed to weathering. Near the South Texas uranium deposits, Galloway and Kaiser (1980) documented paleoweathered volcanic horizons that contain between 2 to $3 \mathrm{ppm}$ uranium, as compared to a range of 7 to 9 ppm uranium in the unweathered parent rocks, suggesting that these horizons contributed significantly to the uranium in the groundwater. Barbier (1974) and Maynard et al. (1995) suggested that uranium liberated during weathering of granitoid rocks was a source of uranium for ore deposition in the Witwatersrand.

Preliminary geochemical data from the pre-Carboniferous saprolite profiles (Fig. 16) indicate that uranium was mobilized by weathering. During moderate weathering the uranium increases, probably the result of remobilization within the weathering profile. In the case of more intense weathering, uranium can be depleted by more than a $40 \%$ relative to fresh granite, reflecting the destruction of the feldspars, biotite, and ferro-magnesium silicates in the saprolite. It should be noted that not all of the pre-Carboniferous geochemical profiles exhibit the same depletion patterns and, therefore, additional sampling will be necessary to quantify the extent of depletion. In addition to the chemical and mineralogical changes in the weathered horizons, a coincident increase occurred in permeability of the saprolite prior to re-lithification, and therefore, 


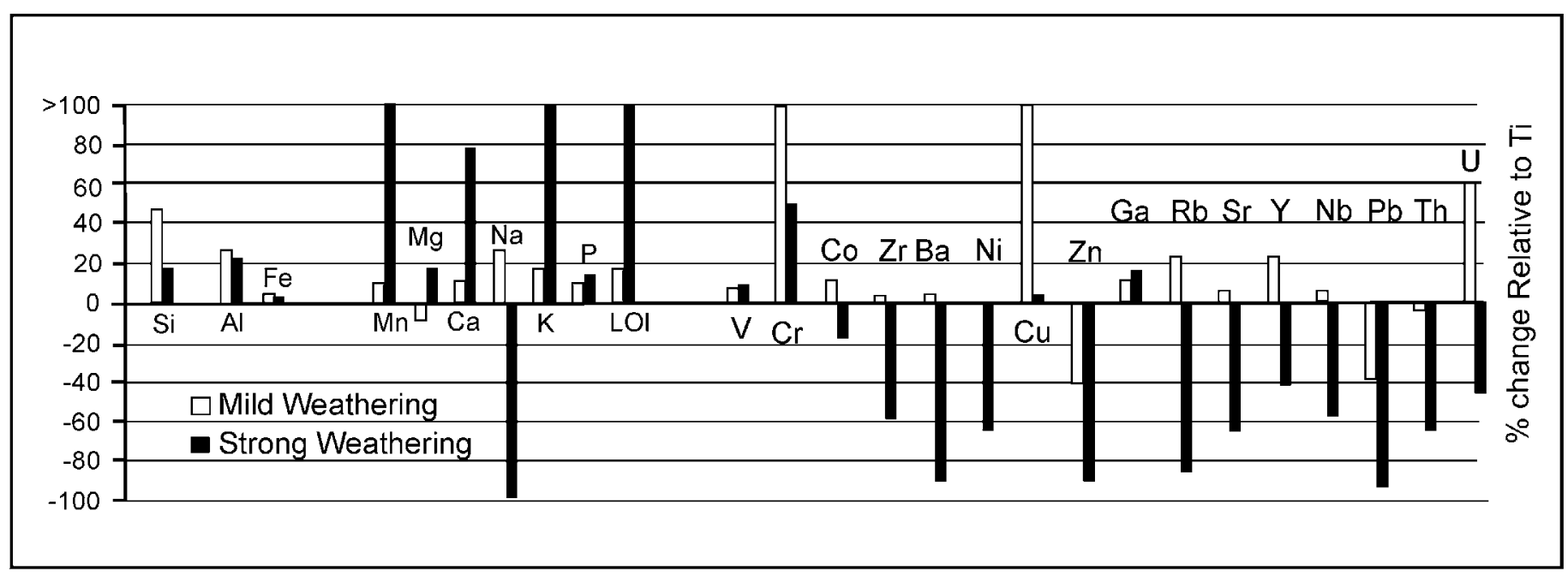

Fig. 16. Relative depletion-enrichment geochemical diagram for the pre-Carboniferous saprolite from a drill hole $4 \mathrm{~km}$ northwest of the Three Mile Plains area. The zero line represents fresh granitoid rocks. Depletions (below the line) and enrichments (above the line) are both given in percents (after O’Beirne-Ryan and Zentilli 2003).

these weathered horizons became preferred conduits for fluid flow in the granitoid units, which in turn created a mechanism for uranium redistribution in the oxidizing near-surface environment.

\section{ENVIRONMENTAL IMPLICATIONS}

The initial exploration and subsequent drilling in the Three Mile Plains area was sparked by the discovery of radon anomalies in the soil gas and radon, uranium, and radium in well waters in the area (Quarch et al. 1979). Consequently, it is inferred that environmental implications are related to these uranium occurrences in the Horton Group. There are two major radonin-soil-gas anomaly areas at Three Mile Plains (Fig. 17), one of which occurs immediately north-northwest and downslope and downstream of the Green Street uranium occurrences, and the other north and downslope of the Maple Brook occurrence.

Kronfeld et al. (2004) studied uranium series isotopes in the Avon Valley, west and southwest of the Three Mile Plains area. Their study found that uranium concentrations in ground and surface waters was generally low, except immediately adjacent to uranium occurrences at Millet Brook. Radon, however, was generally slightly anomalous throughout the area, suggesting continual degassing from uranium-enriched bedrock. Kronfeld et al. (2004) suggested that the relatively low values and wide distribution of radon may be due to constant flushing by the relatively high precipitation rates in the region and the high permeabilities of the sandstone aquifers in the Horton Group. In the Saarberg Interplan sample set, Page (1999) found a strong correlation between dissolved uranium and radon in the waters derived primarily from the Horton Group aquifers. This result contrasts with the lack of correlation in the Kronfeld et al. (2004) data from the Avon River study, which included waters from the South Mountain Batholith as well as the Carboniferous basin-fill units. The samples compiled by Page (1999) were collected by Saarberg Interplan Canada Ltd., with great care taken to minimize the degassing effects within the individual wells, suggesting that the lack of correlation in the Avon Valley data was possibly related to sampling techniques. As part of a geochemical study of the surface and ground waters in the Avon River Drainage Johannessen (2000) pointed out that during the time of sampling of the Kronfield et al (2004) sample set there was a water shortage in the area that precluded running the water from the wells for an appropriate time interval before taking samples. Therefore, degassing of the radon was a probable source of error. Drilled wells generally have higher radon values than dug wells, primarily due to degassing over a larger surface area in dug wells. However, in Saarberg Interplan's regional study, some of the highest radon values in water (up to $1777 \mathrm{~Bq} / \mathrm{L}$ ) were from dug wells in the Three Mile Plains area (Morse and Harder 1979). Morse and Harder (1979) indicated that the concentrations of well water radon in the Three Mile Plains area are comparable to those in studies they had undertaken in uranium-producing areas in Texas. The anomalous values are in excess of 50 times greater than the background values (approx. $31 \mathrm{~Bq} / \mathrm{L}$ ) established by Dyck et al. (1976) for Carboniferous rocks elsewhere in the Maritimes Basin. The existence of any radium in well water above the detection limit of $8 \mathrm{piC} / \mathrm{L}$ was considered anomalous by Morse and Harder (1979). Well waters in the area of the anomalous radon north of the Three Mile Plains occurrences (Page 1999), yielded five radium readings above the detection limit.

Interestingly, radon soil gas and well water anomalies documented by Morse and Harder (1979) are north of the West Branch of the Avon River along Mines Road where drilling revealed no mineralization in Horton Group strata (Fig. 3). The drilling, however, did intersect paleosaprolite underlying the Horton Group up-dip from the radon anomalies. Using GIS Page (1999) also found a moderate GIS correlation between faults and unconformities and higher radon levels in 
well waters. During earlier studies there was an incomplete understanding of the paleoweathering surfaces below the Carboniferous strata in the Maritimes Basin and, therefore, no direct correlation was attempted. The presence of radon and radium anomalies associated with the pre-Carboniferous saprolite in the Mines Road area, in the absence of known rollfront mineralization, clearly demonstrates that areas proximal to saprolite horizons must also be examined for potential uranium, radon, and radium enrichment.

The rate and quantity of uranium and radon contributed to surface and ground waters from mineralized outcrops is not clearly understood, and hence the specific environmental impacts cannot be fully evaluated without further study. Parsons (2007) completed a preliminary experimental study which demonstrated that uranium concentrations above the acceptable limits for drinking water can be attained by placing uranium-bearing samples from the Green Street occurrence in rain, stream water, and distilled water and allowing them to leach for several days. The results of the laboratory experi- ments demonstrate the necessity for greater caution in areas of similar uranium occurrences given the possibility of attaining uranium values higher than the acceptable Health Canada guidelines for drinking water $(>0.02 \mathrm{mg} / \mathrm{l})$. A detailed discussion of this research aspect is beyond the scope of this paper; however, a companion manuscript is currently in preparation.

\section{CONCLUSIONS}

A spatial correlation has been established between pre-Carboniferous paleoweathered surfaces (saprolite) on the South Mountain Batholith and the uranium occurrences associated with roll fronts in Horton Group strata. The uranium occurrences are stratabound, in that they occur immediately above and below the unconformity between the Horton Bluff and overlying Cheverie formations. The unconformity also represents a reduction-oxidation boundary with grey beds dominating the lower formation and red and green strata predominant

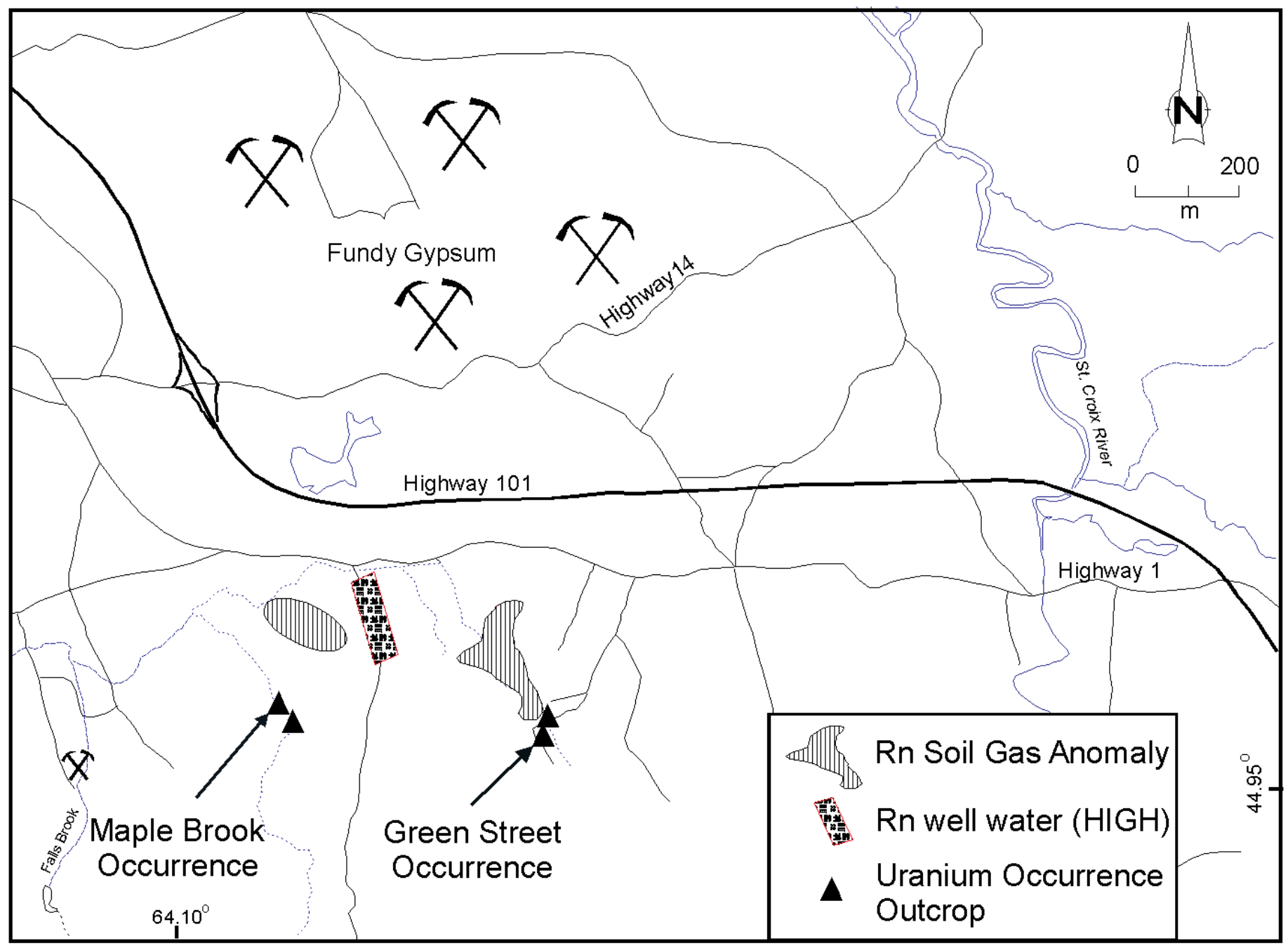

Fig. 17. Location map of radon soil anomalies and radon in well water anomalies in the Three Mile Plains area near Windsor, Nova Scotia. 
in the upper formation. Two types of uranium roll-front mineralization are documented in the area:(1) carbon-pyrite quartz sandstone and (2) hematite arkosic sandstone. The uranium occurrences have associated radon and uranium anomalies in soil and water. Preliminary leaching tests of the mineralized outcrop indicate that uranium levels above the acceptable guidelines can be attained by leaching rock samples with rain, stream or distilled water. The inferences of enrichment and migration of uranium and associated elements from occurrences in the Windsor area of Nova Scotia are applicable to Horton Group strata throughout eastern Canada. Environmental issues related to uranium enrichment probably exist throughout the Maritimes Basin, in particular, in areas where Horton Group strata are adjacent to uranium occurrences in granitoid basement rocks.

\section{ACKNOWLEDGMENTS}

The authors would like to thank the Nova Scotia Department of Natural Resources Geological Services Division and the Faculty of Science at Dalhousie University for their financial support. Thanks to George O’Reilly and Doug MacDonald and the journal reviewers Elisabeth Kosters and Susan Johnston and editor Sandra Barr for their helpful suggestions. Thanks also to Andrea Parsons and Danielle Finlayson for their work on the Green Street Occurrence.

\section{REFERENCES}

Baranov, E. N. 1959. The cause of reddening of rocks enclosing hydrothermal uranium deposits. Atomic Energy 5, pp. 1607-1609. doi:10.1007/BF02285450

Barbier, M. J. 1974. Continental weathering in the possible origin of vein-type uranium deposits. Mineralium Deposita 9, pp. 289-295. doi:10.1007/BF00204001

Bell, W.A. 1929. Horton-Windsor district, Nova Scotia. Geological Survey of Canada Memoir 155, $268 \mathrm{p}$.

Brummer, J. J. 1958. Supergene copper-uranium deposits in northern Nova Scotia. Economic Geology 53, pp. 309-324. doi:10.2113/gsecongeo.53.3.309

Cameron, E. M. 1983. Uranium Exploration in Athabasca Basin, Saskatchewan, Canada. Geological Survey of Canada Paper 82-11, 310 p.

Carruzzo, S. 2003. Granite-hosted mineral deposits of the New Ross area, South Mountain Batholith, Nova Scotia, Canada. Unpublished Ph.D. thesis, Dalhousie University, Halifax, Nova Scotia, $959 \mathrm{p}$.

Chatterjee, A. K., and Muecke, G. K. 1982. Geochemistry and distribution of uranium and thorium in the granitoid rocks of the South Mountain Batholith, Nova Scotia: some genetic and exploration implications. In Uranium in Granites. Edited by Y.T. Maurice. Geological Survey of Canada Paper 81-23, pp. 11-17.

Chatterjee, A.K., Robertson, J., and Pollock, D. 1982. A sum- mary on the petrometallogenesis of the uranium mineralization at Millet Brook, South Mountain Batholith, Nova Scotia. Nova Scotia Department of Mines and Energy Report 782-1, pp. 57-67.

Clarke, D.B., MacDonald, M.A., and Tate, M.C. 1997. Late Devonian mafic-felsic magmatism in the Meguma Zone, Nova Scotia. Geological Society of America Memoir 191, pp. 107-127.

Dahlkamp, F.J. 1984. Characteristics and problematics of metallogenesis of Proterozoic vein-like type uranium deposits. In Syngenesis and Epigenesis in the formation of Mineral Deposits. Edited by A. Wauschkuhn, C. Kluth, and R.A. Zimmermann R. A., Springer Verlag, Berlin, pp. 183-192.

Dunsmore, H. E. 1977. A new genetic model for uranium copper mineralization, Permo-Carboniferous basin, northern Nova Scotia. Current Research, Part B, Geological Survey of Canada Paper 77-1B, pp. 247-253.

Dyck, W., Chatterjee, A.K., Gemmell, D.E., and Murricane, K. 1976. Well water trace element reconnaissance, Eastern Maritime Canada, Journal of Geochemical Exploration, 6, pp. 139-162. doi:10.1016/0375-6742(76)90011-X

Finck, P.W., and Stea, R.R. 1995. The compositional development of tills overlying the South Mountain Batholith, Nova Scotia. Nova Scotia Department of Natural Resources, Minerals and Energy Branch Paper 95-1, 52 p.

Gabelman, J. W. 1977. Migration of uranium and thorium - exploration significance. American Association of Petroleum Geologists, Studies in Geology 3, 168 p.

Galloway, W. E., and Kaiser, W. R. 1980. Catahoula Formation of the Texas Gulf coastal plain, geochemical evolution, and characteristics of the Uranium Deposits. University of Texas, Austin. Bureau of Economic Geology Report of Investigations $100,81 \mathrm{p}$.

Goldhaber, M. B., Reynolds, R. L., and Rye, R. O. 1978. Origin of South Texas uranium deposit:II. Sulphide petrology and sulphur isotope studies. Economic Geology, 73, pp. 16901705. doi:10.2113/gsecongeo.73.8.1690

Gross, G. A. 1957. Uranium deposits in Gaspe, New Brunswick and Nova Scotia. Geological Survey of Canada Paper 57-2, $27 \mathrm{p}$.

Hamblin, A. P., and Rust, B. R. 1989. Tectono-sedimentary analysis of alternate polarity half graben basin-fill sucessions: Late Devonian - Early Carboniferous Horton Group, Cape Breton Island, Nova Scotia. Basin Research 2, pp. 239255. doi:10.1111/j.1365-2117.1989.tb00038.x

Harshman, E. N. 1968. Uranium deposits in the Eocene sandstones of the Powder River Basin, Wyoming. In Ore Deposits of the United States 1933-1967, The Granton Sales Volume. Edited by J.D. Ridge. American Institute of Mining, Metallurgical and Petroleum Engineers. pp. 838-848.

Howie, R.D., and Barss, M.S. 1975. Upper Paleozoic rocks of the Atlantic Provinces, Gulf of St. Lawrence, and adjacent continental shelf, In Offshore Geology of Eastern Canada, Geological Survey of Canada Paper 74-30, pp 35-50.

Johannessen, D.I. 2000. Multi-isotope geochemistry of surface and groundwater in the Avon River Drainage: Hydrogeo- 
logical implications. Unpublished M.Sc. thesis, Dalhousie University, Halifax, Nova Scotia. 120 p.

Keighley, D., and St. Peter, C. 2006. Selected core from the Albert Formation (Mississippian) Moncton Basin, Southern New Brunswick. Canadian Society of Petroleum Geologists CSPG Convention 2006. Extended abstracts volume, pp. 605-615.

Keppie, J. D. 1993. Synthesis of Paleozoic deformational events and terrane accretion in the Canadian Appalachians. Geologische Rundschau, 82, pp. 381-431. doi:10.1007/ BF00212406

Knight, I. 1983. Geology of Carboniferous Bay St. George subbasin, western Newfoundland. Mineral Development Division, Department of Minesand Energy. Government of Newfoundland and Labrador Memoir 1, $158 \mathrm{p}$.

Kronfeld, J., Godfrey-Smith, D.I., Johannessen, D., and Zentilli, M. 2004. Uranium series isotopes in the Avon Valley, Nova Scotia. Journal of Environmental Radioactivity 73, pp. 335-352. doi:10.1016/j.jenvrad.2003.11.002

Lidmar-Bergstrom, K., Olsson, S., and Olvmo, M. 1997. Paleosurfaces and associated saprolites in southern Sweden. In Paleosurfaces, recognition, reconstruction and paleoenvironmental interpretation. Edited by $\mathrm{M}$. Widdowson. Geological Society Special Publication 120, pp. 95-124.

MacDonald, M.A. 2001 Geology of the South Mountain Batholith, Southwestern Nova Scotia. Nova Scotia Department of Natural Resources Minerals and Energy Branch Open File Report ME 2001-2, 281 p.

MacDonald, M.A., Horne, R.J., Corey, M.C., and Ham, L.J. 1992. An overview of recent mapping and follow-up petrographic studies of the South Mountain Batholith, Nova Scotia, Canada. Atlantic Geology 28, p 7-28.

Martel, T., and Gibling, M. 1996. Stratigraphy and tectonic history of the upper Devonian to lower Carboniferous Horton Bluff Formation, Nova Scotia. Atlantic Geology 32, pp. 13-38.

Maynard, J.B. 1983. Geochemistry of sedimentary ore deposits. Springer-Verlag, New York, 305 p.

Maynard, J.B., Sutton, S.J., Robb, L.J., Ferraz, M.F., and Meyer F.M. 1995. A paleosol developed on hydrothermally altered granite from the hinterland of the Witwatersrand Basin: Characteristics of a source of basin fill. Journal of Geology 103, pp. 357-377. doi:10.1086/629757

Moore, R. G., and Ferguson, S. A. 1986. Geological map of the Windsor area, Nova Scotia, parts of NTS 21A/16 and $21 \mathrm{H} / 01$. Nova Scotia Department of Mines and Energy Map 86-2, scale 1:25000.

Morse, R.H., and Harder, D.G. 1979. Uranium exploration Property No. 1, Windsor, Nova Scotia, Saarberg Interplan Canada Ltd. Nova Scotia Department of Natural Resources Assessment Report 54-I-57-04, 22 p.

Murray, B.C. 1960. Stratigraphy of the Horton Group in parts of Nova Scotia. Nova Scotia Department of Natural Resources Open File Report ME 583, 128 p.

O’Beirne-Ryan, A.M., and Zentilli, M. 2003. Paleoweathered surfaces on granitoid rocks of southern Nova Scotia: pa- leoenvironmental implications of saprolites. Canadian Journal of Earth Sciences 40, pp. 805-817. doi:10.1139/e03-016

Page, K. D. 1999. Uranium, Radium and Radon in streams, domestic well waters, and soils: a GIS analysis of geological, geochemical and geophysical relationships. Unpublished B.Sc. Honours Thesis. Dalhousie University, Halifax, Nova Scotia, $298 \mathrm{p}$.

Parsons, A. 2007. Potential for uranium mobility from weathered outcrop of uranium-bearing strata, southern Nova Scotia. Unpublished B.Sc. Honours Thesis. Dalhousie University, Halifax, Nova Scotia, $67 \mathrm{p}$.

Phillips, G.N., and Myers, R.E. 1989. The Witwatersrand gold fields: Part II. An origin for Witwatersrand gold during metamorphism and associated alteration. Economic Geology Monograph 6, pp. 598-608.

Quarch, H., Rikeit, K., and Ryan, R. J. 1979. Uranium Exploration, Windsor Nova Scotia. Nova Scotia Department of Mines and Energy Assessment Report 54-I-57-03, 29 p.

Ryan, R.J. 1998. The Falls Brook Quarry near Three Mile Plains, Windsor, Nova Scotia. In Classic Carboniferous Sections of the Minas and Cumberland Basins in Nova Scotia. Edited by J.H. Calder, R.C. Boehner, D.E. Brown, M. Gibling, P.K. Mukhophyay, R.J. Ryan, and D. Skilliter. Nova Scotia Department of Natural Resources, Minerals and Energy Branch, Open File Report ME-1998-5, pp. 15-24.

Ryan, R.J., and O'Beirne-Ryan, A.M. 2007. Preliminary report on the uranium occurrences in the Horton Group of the Windsor area, Nova Scotia. In Nova Scotia Department of Natural Resources Report of Activities. Edited by D. MacDonald. Mines and Minerals Branch Report 2007-1, pp. 137-157.

Ryan, R.J., and Zentilli, M. 1993. Thermochronological and allocyclic contraints on the evolution of the Maritimes Basin. Atlantic Geology 29, pp. 187-197.

Ryan, R. J., Boehner, R. C., and Calder, J. H. 1991. Lithostratigraphic Revisions of the Upper Carboniferous to lower Permian strata in the Cumberland Basin, Nova Scotia and the regional implications for the Maritimes Basin of Eastern Canada. Bulletin of Canadian Petroleum Geology 39, pp. 289-314.

Ryan, R.J., O'Beirne-Ryan, A.M., and Zentilli, M. 2005. Rounded cobbles that have not traveled far: incorporation of corestones from saprolites in the South Mountain area of southern Nova Scotia. Sedimentology 52, pp. 1109-1121. doi:10.1111/j.1365-3091.2005.00730.x

Schenk, P.E. 1995. Meguma Zone. In Geology of the Appalachian-Caledonian Orogen in Canada and Greenland. Edited by $\mathrm{H}$. Williams. Geological Survey of Canada, Geology of Canada, No. 6, Chapter 3, pp. 261-277.

Stea, R.R., and Pullan, S.E. 2001. Hidden Cretaceous Basins in Nova Scotia. Canadian Journal Earth Science 38, pp 13351354. doi:10.1139/cjes-38-9-1335

Sutton, S.J., Ritger, S.D., and Maynard, J.B. 1990. Stratigraphic control of chemistry and mineralogy in metamorphosed Witwatersrand quartzites. Journal of Geology 98, pp. 329341. doi:10.1086/629408 
St. Peter, C. 1993. Maritimes Basin evolution: key geologic and seismic evidence from the Moncton Subbasin of New Brunswick. Atlantic Geology 29, pp. 233-270.

Teniere, P. J., Barr, S. M., and White, C. E. 2005. Stratigraphy and structure of the Horton Group, Locharber-Mulgrave area, northern mainland Nova Scotia. Atlantic Geology 41, pp. 41-52.

Tibert, N. E., and Scott, D. B. 1999. Ostracodes and agglutinated foraminifera as indicators of paleoenvironmental change in an early Carboniferous brackish bay, Atlantic Canada. Palaios 14, pp. 246-260. doi:10.2307/3515437

Utting, J., Keppie, J.D., and Giles, P.S. 1989. Palynology and stratigraphy of the Lower Carboniferous Horton Group, Nova Scotia. In Contributions to Canadian Paleontology. Edited by L. Reynolds. Geological Survey of Canada Bulletin 396, pp. 117-143.

Van de Poll, H.W., and Ryan, R.J. 1985. Lithostratigraphic, Physical diagenetic and Economic Aspects of the Pennsylvanian to Permian transition sequence of Prince Edward
Island and Nova Scotia. Geological Association of Canada, Guidebook Excursion 14, 109 p.

Weil, J. A. 1975. The aluminum centers in $\alpha$-quartz. Radiation effects and defects in solids, 26, pp. 261-265. doi: $10.1080 / 00337577508232999$

Weir, S. L. 2002. Invertebrate Ichnofossils of the Horton Bluff Formation in the collections of the Nova Scotia Museum of Natural History. Unpublished B.Sc. Thesis, St. Mary's University, Halifax, Nova Scotia, 89 p.

Williams, H. 1995. Introduction. In Geology of the Appalachian Orogeny in Canada and Greenland. Edited by H. Williams. Geological Survey of Canada, Geology of Canada, 6, pp.1-18.

Zielinski, R. A., Bloch, S., and Walker, T. R. 1983. The mobility and distribution of Heavy Metals during the formation of first cycle red beds. Economic Geology 78, pp. 1574-1589. doi:10.2113/gsecongeo.78.8.1574

Editorial responsibility: Sandra M. Barr 